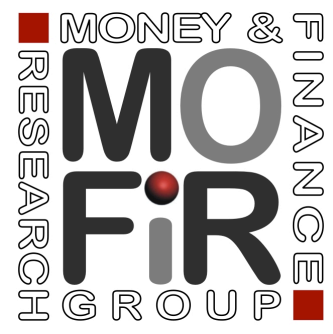

\title{
DOMESTIC PUBLIC DEBT IN LOW-INCOME COUNTRIES: TRENDS AND STRUCTURE
}

\author{
Giovanna Bua Juan Pradelli
}

Andrea F. Presbitero

Working paper no. 85 


\title{
Domestic public debt in low-income countries: trends and structure*
}

\author{
Giovanna Bua \\ The World Bank \\ Università Statale di Milano
}

\author{
Juan Pradelli \\ The World Bank
}

\author{
Andrea F. Presbitero \\ Università Politecnica delle \\ Marche \& MoFiR
}

\begin{abstract}
This paper introduces a new dataset on the stock and structure of domestic debt in 36 LowIncome Countries over the period 1971-2011. We characterize the recent trends regarding LICs domestic public debt and explore the relevance of different arguments put forward on the benefits and costs of government borrowing in local public debt markets. The main stylized fact emerging from the data is the increase in domestic government debt since 1996. We also observe that poor countries have been able to increase the share of long-term instruments over time and that the maturity lengthening went together with a decrease in borrowing costs. However, the concentration of the investor base, mainly dominated by commercial banks and the Central Bank, may crowd out lending to the private sector.
\end{abstract}

JEL Codes: E62; H63; O23

Keywords: Domestic debt; Debt structure; Low-income countries, HIPCs

* The findings, interpretations, and conclusions expressed in this paper are entirely those of the authors. They do not necessarily represent the views of the International Bank for Reconstruction and Development/World Bank and its affiliated organizations, or those of the Executive Directors of the World Bank or the governments they represent. We gratefully acknowledge the financial support of the World Bank's Research Support Budget. We also thank Reza Baqir and Alessandro Missale for comments on an earlier draft. 


\section{Introduction}

Analyses on government borrowing and debt management in Low Income Countries (LICs) have traditionally focused on external debt. This scarcity of studies is partly due to the lack of a comprehensive database on domestic public debt and the historical prominence of external borrowing compared to domestic borrowing. Until recently, in fact, foreign liabilities have been the largest component of the public debt in LICs, the target of debt relief initiatives such as Heavily Indebted Poor Countries (HIPC) and Multilateral Debt Relief Initiative (MDRI), and the main concern of the joint Fund/Bank Debt Sustainability Framework for LICs (LIC DSF). In recent years, however, LICs made substantial efforts to develop their local public debt markets and relied heavily on domestic sources to finance budget deficits during the global crisis, sparking the attention of International Financial Institutions (IFIs) and the academic community.

Because of the constraints indicated above, the existing literature on government borrowing in LICs is relative scant and inconclusive with regard to the benefits and cost of domestic liabilities relative to foreign liabilities. Only few studies assess empirically the rationale (if any) for LIC governments to gradually shift their financing strategies towards domestic sources and away from external sources.

At any rate, domestic financing is plenty of advantages. The literature on public debt management in Emerging Markets (EMs) has shown that, in general, market depth has increased, maturities have lengthened and the investor base has broadened (Mehrotra, Miyajima and Villar, 2012). As a result, domestic debt may bring some prominent benefits: the lower exposure of the public debt portfolio to currency risk if and when the domestic debt is denominated in local currency (Hausmann, Panizza and Rigobon, 2006; Bacchiocchi and Missale 2012); a lower vulnerability to capital flow reversals (Calvo, 2005); the possibility to undertake countercyclical monetary policy to mitigate the effect of external shocks (Mehrotra, Miyajima and Villar, 2012); and the improved institutional infrastructure underlying the organization and functioning of local financial markets (Arnone and Presbitero, 2010). In general, long-term domestic currencydenominated debt reduces maturity and currency mismatches and hence tends to be safer.

However, the literature also stresses that domestic borrowing brings benefits only in the presence of a sound institutional and macroeconomic framework, and only if the debt structure features certain characteristics (Abbas and Christensen, 2010, Arnone and Presbitero, 2010, Hausmann, Panizza and Rigobon, 2006, Panizza, 2008, Presbitero, 2012b). Many developing countries are, in fact, unable to issue long-term government securities at a reasonable cost, so they are more vulnerable to rollover and interest rate risks. Moreover, domestic currencydenominated debt could substitute inflation risk for currency mismatch. The nature of the credit base may also raise vulnerabilities. Previous studies underlie the importance of a diverse investor base for lowering the cost of government debt and the volatility of market yield, and stress that a lenders' profile strongly biased toward commercial banks might worsen crowding out effects and reduce the efficiency of the banking system. Yet another aspect of the debt structure that influences vulnerability is the type of instruments issued. According to Abbas and Christensen (2010), many of the benefits of domestic debt market - saving assets, collateral function, benchmark yield curve for private lending - apply to securitized domestic debt and not to liabilities is- 
sued in captive markets or accumulated due to poor public financial management (such as arrears).

The cost-benefit analysis of financial instruments available to the government, as described above, is largely discussed with regards to EMs, while the lack of data on domestic public debt in LICs - especially the financial terms applied to domestic liabilities - has prevented extending the analysis to poorer countries along similar lines. In particular, it hindered the possibility of discussing the rationale for LICs government to increase domestic borrowing relative to external indebtedness.

Against this backdrop, the main objective of this paper is to fill the void in the literature by constructing a brand new database on domestic public debt in LICs. While the existing datasets mainly provide information on the stock of domestic debt and interest payments, at best, our dataset also includes detailed information on maturity, currency composition, creditor base, and type of instruments. The up-to-date information on domestic debt stock and structure is comparable across LICs.

Based on our dataset, this paper characterizes the recent trends regarding LIC domestic public debt and explores the relevance of different arguments put forward on the benefits and costs of government borrowing in local public debt markets. The main stylized fact that emerges from the data is the increase in domestic government debt during the period 1996-2011 and its larger burden with respect to external public debt, at least since the mid-2000s. Short-term financing is mainly instrumented through marketable and non-marketable securities held by the banking system. Central Bank advances to the Treasury, which are typically rolled over, constitute a relevant source of long-term financing. The breakdown into HIPCs and non-HIPCs highlights significant differences in the evolution and structure of domestic debt between the two groups, with HIPCs relying more on Central Bank advances and non-HIPCs making progress in issuing securities and lengthening maturities.

The paper is structured as follow. Section 2 revises the existing literature and databases on domestic public debt in LICs. Section 3 describes our dataset and Section 4 presents some stylized facts on the evolution and structure of domestic public debt. Section 5 concludes.

\section{Domestic Public Debt Management}

\subsection{Fiscal deficit financing}

Fisher and Easterly (1990) identify four different means of fiscal deficit financing and associate each of them with the risk of building certain macroeconomic imbalances: 1) printing money might fuel inflation, 2) running down foreign exchange reserves might trigger an exchange crisis, 3) borrowing abroad might end up in an external debt crisis, and 4) borrowing domestically might increase interest rates and lead also to a debt crisis.

In theory, the seignorage revenue the government can expect to obtain from printing money is non-linear in the inflation rate, similarly to a conventional Laffer curve. The link be- 
tween money creation and inflation is well-known. In practice, however, seignorage is often a small source of resources both for developing and developed countries. Empirical evidence shows that in normal times, the maximum amount of seignorage revenue collected over an extended period of time is less than 5 percent of GDP (Easterly and Schmidt Hebbel, 1991). During fiscal crisis episodes, the seignorage can become an important (albeit temporary) means of deficit financing (Reinhart and Rogoff, 2009). By running down international reserves, instead of printing money, the government can hope to put off the inflationary effects of a fiscal deficit. This policy is also temporary because it can last just until reserves are depleted, or probably collapse even earlier as pointed out by the theoretical and empirical literature on currency crisis.

Foreign borrowing allows to finance the fiscal deficit without creating money supplydriven inflationary pressures or crowding out domestic lending to the private sector. However, external credit flows tend to be volatile, procyclical, and subject to sudden stops (Calvo, 2005). By providing not only financing but also foreign exchange, foreign borrowing may induce a real exchange rate appreciation, thus hampering competitiveness and possibly lowering investment and economic growth (Rodrik, 2008). External debt is typically denominated in foreign currency and this creates additional constraints on monetary policy and exchange rate management. For instance, according to Hausmann (2003), foreign currency-denominated debt lowers the evaluation of solvency because it heightens the dependence of debt service on the evolution of the exchange rate, which is often volatile and subject to shocks and crises. Cespedes, Chang and Velasco (2003) underline that, when there are currency mismatches in the balance sheets of local agents, currency devaluations are contractionary since they induce negative net wealth effects. Under these circumstances, Hausmann and Rigobon (2003) maintain that central banks are reluctant to let the exchange rate float and tend to intervene aggressively in the foreign exchange market and hold more international reserves.

Domestic borrowing, typically denominated in local currency, does not bring about some complications associated with external credit flows. The most prominent concern, instead, is the crowding out effect: issuing domestic debt the governments taps private savings that would otherwise be available to finance private investment. If market-determined interest rates increase, this may reduce investment demand. And if interest rates are controlled or lenders are reluctant to raise them to avoid adverse selection and moral hazard problems, the domestic government borrowing can lead to credit rationing and a reduced supply of funds for private investment.

\subsection{Domestic financing in LICs}

The theoretical literature on government borrowing and public debt management in LICs is relatively scant - at least compared to advanced economies and emerging markets - and still inconclusive with regard to the benefits and costs of domestic liabilities relative to foreign liabilities. Empirical work, in particular, has been constrained by the lack of a comprehensive domestic public debt database and by the traditional emphasis placed on external borrowing as the main means of fiscal deficit financing in poor countries. The few available studies on LIC government debt reviewed in Table 1 gathered data from multiple sources that were deemed adequate for 
specific analytical purposes. ${ }^{1}$ Available data on domestic public debt are therefore quite heterogeneous in terms of the criteria to distinguish domestic and external debt, the definition of public sector, the type of government liabilities covered, and the treatment of certain financial arrangements (e.g., on-lending operations, IMF lending to central banks under a sovereign guarantee, liabilities issued in regional capital markets). Furthermore, to the best of our knowledge, no dataset provides information on the structure of domestic public debt.

Domestic public debt started increasing in LICs from the mid-1990s, in coincidence with an upsurge in financial liberalization (Presbitero, 2012b). Subsequently, in the wake of the debt relief initiatives and the recent global financial crisis, the level and composition of public debt in LICs have changed, sparking the attention of IFIs and the academic community. ${ }^{2}$

In policy-oriented discussions on government borrowing and public debt management in LICs, a common presumption is that domestic financing is more expensive and riskier than external financing, thus making foreign debt preferable to domestic debt. Supporting this view, Christensen (2005) analyses the structure of public debt in 27 Sub-Saharan African countries and finds that domestic debt represents a significant burden to the budget in terms of interest payments, notwithstanding having a relatively small size. In addition, the author shows that the short-term maturity of domestic government debt is a source of rollover risk and macroeconomic instability, and documents the existence of crowding out effects on private-sector borrowing.

LICs benefiting from debt relief initiatives have attracted special attention of policy makers and researchers because of the expectations that these initiatives would help poor countries to stabilize the economy, strengthen public finances, free budget resources to finance the provision of social services and infrastructure, and implement structural reforms. In their study on debt relief and HIPCs, Arnone and Presbitero (2010) analyze the evolution and costs of domestic government debt using a World Bank dataset covering 79 developing countries in 1970-2003. They provide evidence that both the stock of domestic public debt and the associated interest payments rose in HIPCs after receiving relief. Presbitero (2012b) shows that, in fact, the reliance on internal financing has partially offset the reduction in external debt granted by multilateral and bilateral debt relief initiatives. Arnone and Presbitero (2010) argue that such trends might put forward risks to sustainable economic development and thus jeopardize the objective of spurting growth that motivated granting debt relief in the first place. Furthermore, they suggest that the objectives of creating a stable macroeconomic environment and developing local financial markets have not been reached yet. This should be a concern because the experience of EMs since the early 2000s suggests that macroeconomic stability and financial deepening are necessary for domestic public debt not to represent yet another factor of vulnerability (Borensztein, LevyYeyati, and Panizza, 2006). In this regard, Presbitero (2012b) shows that only countries with sound policies and institutions exhibit a pattern of rising domestic public debt and upbeat macroeconomic performance in terms of greater capital accumulation, stronger output growth, and

\footnotetext{
${ }^{1}$ These sources include the IMF's Monetary Survey, Staff Reports, and Article IV Reports; the World Bank's World Development Indicators and Global Development Finance database; and, if available, the websites of LICs' central banks and ministries of finance.

${ }^{2}$ In February 2012, the IMF's and IDA's Board drew attention to the fiscal vulnerabilities stemming from an increasing public debt in LICs, and recommended the development of benchmarks (thresholds) for total public debt in order to strengthen the LIC DSF and inform policy dialogue with country authorities (IMF-IDA, 2012).
} 
faster financial development. Such a salutary correlation is not observed in countries with a weak institutional environment.

The increasing domestic borrowing in LICs, especially in those that benefited from debt relief, begs for an explanation. One strand of the literature challenges upfront the common presumption that domestic financing is costlier than external financing in LICs. Abbas (2005) argues that the lack of recurrent domestic sovereign defaults in poor countries might be an insight that servicing domestic debt is actually easier than repaying foreign debt, and, in a similar vein, Panizza (2008) maintains that switching the sources of fiscal deficit financing towards domestic debt might reduce the risk of sovereign defaults. Another strand moves away from purely costrisk considerations and emphasizes supply-side constraints: facing decreasing foreign aid (including both lending and grants) relative to development financing needs, LIC governments must seek for additional domestic funding sources. Some authors argue that external credit constraints imposed by private lenders, or policy conditionality restricting non-concessional foreign borrowing imposed by IFIs, have reduced the opportunities for external financing and forced LIC governments to tap local public debt markets (Arnone and Presbitero, 2010). ${ }^{3}$ Structural benchmarks in recent IMF programs seek to foster the development of local markets for government securities, thus ultimately favoring domestic financing (IMF and World Bank, 2001; UNCTAD, 2004; Borensztein, Levy-Yeyati, and Panizza, 2006; Arnone and Presbitero, 2010). Finally, other studies depart from the hypothesis that LIC governments use domestic public debt mainly for fiscal deficit financing, and argue that internal borrowing help sterilizing foreign exchange inflows from foreign aid or natural resource-based exports, particularly in LICs pursuing an active exchange rate management but unable or unwilling to use monetary policy for sterilization purposes (Christensen, 2005; Aiyar, Berg, and Hussain, 2005).

An alternative rationale for the rising domestic borrowing in LICs is suggested by the literature on public debt management in EMs, which also increased reliance on local financial markets since the early 2000s. Focusing on demand-side factors, a number of studies investigate an EM government's preferred debt portfolio composition and the cost-risk profile of financial instruments available, identifying important pros and cons of shifting from external to domestic borrowing. To the extent that internal financing is denominated in local currency, domestic debt reduces the exposure of the public debt portfolio to unanticipated movements in the exchange rate (Hausmann, Panizza, and Rigobon, 2006; Bacchiocchi and Missale, 2012) and ensures a higher degree of freedom to use the exchange rate as a stabilization mechanism against external shocks, i.e. lower fiscal dominance on the exchange rate policy (IMF and World Bank, 2001; Kumhof and Tanner, 2005). Also, to the extent that domestic debt is owed to resident creditors, it reduces exposure to capital flow reversals (Calvo, 2005). Domestic borrowing can improve the efficiency of the allocation of national savings if mobilized resources are used to fund public investment and not capital flight or inefficient self-investment by savers (Abbas and Christensen, 2010). Building the institutional infrastructure for the issuance of domestic public debt often

\footnotetext{
${ }^{3}$ IMF-supported programs in LICs typically include limits on non-concessional external debt, under the Debt Limits Policy (DLP), which seek to prevent the build-up of unsustainable debt while allowing for adequate external financing (IMF, 2009). Along the same line, the World Bank lending to LICs follows the Non-Concessional Borrowing Policy (NCBP), an incentive mechanism aimed at discouraging high-risk countries that receive grants from contracting non-concessional external debt (IDA, 2006). Neither the DLP nor the NCBP apply to domestic public debt.
} 
supports the organization and functioning of local financial markets (Arnone and Presbitero, 2010).

On the other hand, the literature on EMs explores the disadvantages of domestic borrowing. Given that many developing countries are unable to issue long-term government securities at a reasonable interest rate, the resulting maturity mismatch can be worse than the currency mismatch associated with foreign debt (Panizza, 2008). Macroeconomic distortions and instability can be induced by an excessive domestic borrowing, including crowding out effects (Hanson, 2007; Panizza, 2008; Abbas and Christensen, 2010; and Arnone and Presbitero, 2010) and the association of large domestic debts with hyper-inflation episodes and external debt crisis (Reinhart and Rogoff, 2009). Distortions in the financial system can be also important, particularly the potentially perverse incentives facing financial institutions that invest in government debt. For instance, banks investing in public debt are more profitable but less efficient, and they are more likely to prefer short term portfolio allocation and thus build additional vulnerabilities; domestic banks and institutional investors may be induced by moral suasion to absorb excessive public debt (Hauner, 2006; Hanson, 2007; Panizza, 2008; and Arnone and Presbitero, 2010).

Some studies focus on the role of macroeconomic, political, and institutional factors in determining the composition of total public debt in terms of domestic and external liabilities. Earlier contributions in the original sin literature attempt to explain why external liabilities are denominated in a few currencies and why domestic liabilities are short term (Eichengreen and Hausmann, 1999; Eichengreen, Hausmann and Panizza, 2003; Hausmann and Panizza, 2003; Jeanne, 2003; and Mehl and Reynaud, 2005). Guscina (2008) finds that in EMs, low and stable inflation and deep financial markets are associated with a higher share of domestic liabilities in the public debt portfolio of the central government. Along the same line, Diouf and Doufrense (2012) study the security market in the WAEMU and identify demand- and supply-side factors that might hamper the issuance of long-term domestic debt instruments.

While these arguments are largely discussed with regard to EMs, the lack of data on domestic public debt, especially with regard to financing terms applied to domestic liabilities, has prevented extending the analysis to LICs along similar lines.

At a macroeconomic level, the balance of costs and benefits of domestic borrowing in LICs could be reflected in the effect of domestic public debt on economic growth. To the best of our knowledge, Abbas and Christensen (2010) is the only paper that explicitly addresses this issue in a sample of developing countries that includes a sufficiently large number of LICs. The authors find that domestic public debt has a positive impact on output growth provided that it does not exceed 35 per cent of bank deposits; above this threshold, debt undermines economic activity through crowding out effects and inflationary pressures. The financing terms applied to government liabilities also matter: the growth effect of domestic public debt is higher for marketable instruments that bear positive real interest rates and are held by non-bank investors. ${ }^{4}$

\footnotetext{
${ }^{4}$ Presbitero (2012a) investigates the impact of total (external and domestic) public debt on output growth in a sample of 92 developing countries and finds that debt has a negative impact on growth up to a threshold of 90 percent of GDP, beyond which the effect becomes irrelevant. This non-linear effect is consistent with debt hindering growth only in countries with sound macroeconomic policies and stable institutions. By contrast, in countries where macroeconomic policies are weak, these are likely to be the first-order constrain on growth.
} 
Table 1: Databases on LIC public debt.

\begin{tabular}{|c|c|c|c|c|c|}
\hline Database & $\begin{array}{l}\text { Country } \\
\text { coverage }\end{array}$ & $\begin{array}{c}\text { Domestic debt } \\
\text { definition }\end{array}$ & Public-sector definition & Liabilities included & Observations \\
\hline \begin{tabular}{|l} 
Christensen (2005) \\
(2)
\end{tabular} & \begin{tabular}{|l|}
27 non CFA Sub- \\
Saharan African \\
countries (of which \\
15 LICs) over 1980- \\
2000.
\end{tabular} & Not defined. & Central Government. & $\begin{array}{l}\text { Domestic debt is defined as gross securitized government } \\
\text { debt composed of treasury bills, development stocks, and } \\
\text { bonds. It excludes arrears, advances from the central bank, } \\
\text { and commercial bank loans. }\end{array}$ & $\begin{array}{l}\text { The dataset has limited country } \\
\text { coverage. It contains information on } \\
\text { domestic debt structure for } 15 \text { LICs } \\
\text { up to } 2000 .\end{array}$ \\
\hline $\begin{array}{l}\text { Arnone and } \\
\text { Pres bitero (2010) }\end{array}$ & \begin{tabular}{|l|}
79 developing \\
countries (of which \\
17 LICs) over 1994- \\
2003.
\end{tabular} & $\begin{array}{l}\text { Domestic debt is } \\
\text { defined as debt owed } \\
\text { to creditor resident in } \\
\text { the same country. }\end{array}$ & Central Government. & $\begin{array}{l}\text { Domestic debt is defined as gross securitized government } \\
\text { debt, including treasury bills, bonds, notes, and government } \\
\text { stocks. It excludes arrears, advances from the central bank, } \\
\text { commercial banks loans, debentures, and government } \\
\text { guaranteed debt. }\end{array}$ & $\begin{array}{l}\text { The dataset contains information on } \\
\text { domestic debt structure for } 17 \text { LICs } \\
\text { up to } 2003 \text {. }\end{array}$ \\
\hline \begin{tabular}{|l} 
Abbas and \\
Christensen (2010)
\end{tabular} & $\begin{array}{l}93 \text { LICs and } \\
\text { emerging markets } \\
\text { over 1970-2007. }\end{array}$ & $\begin{array}{l}\text { Domestic debt is } \\
\text { defined as domestic } \\
\text { currency debt owed } \\
\text { to domestic citizens. }\end{array}$ & Central Government. & $\begin{array}{l}\text { Domestic debt is defined as commercial bank's gross claims } \\
\text { on the Central Government plus central bank liquidity paper. }\end{array}$ & $\begin{array}{l}\text { The dataset excludes government } \\
\text { debt held by retail investors and } \\
\text { non-banking institutions. }\end{array}$ \\
\hline Abbas et al. (2010) & $\begin{array}{l}174 \text { countries in } \\
1791-2009 . \text { For LICS } \\
\text { the data coverage } \\
\text { starts in } 1970 .\end{array}$ & Different definitions. & $\begin{array}{l}\text { General Government (or } \\
\text { Central Government if no } \\
\text { data on General Government } \\
\text { are available). }\end{array}$ & $\begin{array}{l}\text { It provides data on total public debt (external plus domestic). } \\
\text { Public debt data are collected from different sources and } \\
\text { liabilities included in the definition might differ across } \\
\text { countries. }\end{array}$ & $\begin{array}{l}\text { Definitions of public debt differ } \\
\text { across countries. The paper does } \\
\text { not disaggregate public debt into } \\
\text { external and domestic. }\end{array}$ \\
\hline Panizza (2008) & $\begin{array}{l}130 \text { countries over } \\
1990-2007 .\end{array}$ & $\begin{array}{l}\text { Domestic debt is } \\
\text { defined as debt } \\
\text { issued under the } \\
\text { jurisdiction of a local } \\
\text { court. }\end{array}$ & $\begin{array}{l}\text { Central Government (or } \\
\text { General Government if no } \\
\text { data on Central Government } \\
\text { are available). }\end{array}$ & $\begin{array}{l}\text { It provides data on total public debt (external and domestic). } \\
\text { Public debt data are collected from different sources and } \\
\text { liabilities included in the definition might differ across } \\
\text { countries. }\end{array}$ & $\begin{array}{l}\text { Public sector definition and } \\
\text { liabilities differ across countries. }\end{array}$ \\
\hline Pres bitero (2012b) & $\begin{array}{l}44 \text { LICs over } 1970- \\
2010 \text { (data are } \\
\text { available for } 41 \\
\text { LICs). }\end{array}$ & Different definitions. & $\begin{array}{l}\text { Central Government (or } \\
\text { General Government if no } \\
\text { data on Central Government } \\
\text { are available). }\end{array}$ & $\begin{array}{l}\text { It provides data on domestic public debt, collected from } \\
\text { different sources and liabilities included in the definition } \\
\text { might differ across countries. }\end{array}$ & $\begin{array}{l}\text { This is an extension and an update } \\
\text { of the Panizza (2008) data set. }\end{array}$ \\
\hline
\end{tabular}




\section{Domestic Public Debt in LICs: A New Dataset}

The Government Finance Statistics Manual (GFSM) prepared by the IMF (IMF, 2001) defines debt as "all liabilities that require payments of interest and/or principal by the debtor to the creditor at a date or dates in the future. Thus, all liabilities in the GFS system are debt except for shares and other equity and financial derivatives". The definition of domestic debt, as opposed to external debt, is not unique and three criteria are common in practice. On a creditor residency basis, debt is domestic if owed to residents. ${ }^{5}$ This criterion is widely used in the compilation of statistical information on government debt by official agencies following the GFSM (IMF, 2001), and is relevant to study international risk sharing and resource transfers between residents and non-residents. On a currency basis, debt is domestic if denominated in local currency. This definition enables the analysis of currency mismatch and vulnerabilities associated with the currency composition of the public debt portfolio. Finally, on a jurisdiction basis, debt is domestic if issued in local financial markets and subjected to the jurisdiction of a local court. This definition helps recognizing the implications of debt restructuring procedures. ${ }^{6}$ Defining unambiguously domestic versus external debt is crucial, since the debt definition affects the identification of vulnerabilities and the conclusions drawn from empirical studies (Panizza, 2008).

Other dimensions are also relevant to characterize the public-sector domestic debt, most notably the definition of public sector (i.e., Central Government, General Government, or Public Sector) ${ }^{7}$ and the type of financial liabilities included in the debt statistics (i.e., market versus nonmarketable instruments). In LICs, the Central Government debt is typically better recorded and thus most studies focus on it. ${ }^{8}$ Similarly, marketable debt instruments are usually better reported than other government liabilities. Information on domestic debts instrumented through loans, securities $^{9}$, and other accounts payable (e.g., Central Bank advances) is relatively more accessible and transparent than on insurance technical reserves and financial derivatives. ${ }^{10}$

\footnotetext{
${ }^{5}$ The concept of residence in the GFSM (IMF, 2001) is not based on nationality or legal criteria, but on economic interest: an institutional unit is said to be a resident unit of a certain country when it has a center of economic interest in the territory of that country. A similar concept of residence is used in the 1993 United Nations System of National Account, the Fifth Edition of the IMF Balance of Payment Manual, and in the IMF Monetary and Financial Statistics.

${ }^{6}$ According to Sturzenegger and Zettelmeyer (2006), sovereign bonds come with an array of contractual features, e.g., covenants, commitments to undertake (or not) certain actions over lifetime of the bond, remedies in the event that contractual obligations are breached, and procedures for modifying the contract. Contractual clauses often differ according to the law under which the sovereign bonds fall and hence they have different implications for the scope and term of debt restructurings.

${ }^{7}$ In the GFSM (IMF, 2001), the General Government consists of all the governments units as well as the non-market non-for-profit institutions controlled and financed by government units. The General Government can be classified in: (i) Central Government, whose authority extends over the entire territory of the country; (ii) State Government, whose authority extends over the largest geographic area into which a country may be divided for political or administrative purposes; and (iii) Local Government, whose authority is restricted to the smallest geographic areas distinguished for political or administrative purposes. The Public Sector includes the General Government, the Public Corporations controlled by government units that engage in financial and non-financial activities, and the Central Bank.

${ }^{8}$ However, this implies that for countries that are highly decentralized with subnational governments that do borrow, or for countries that have large state-owned enterprises that issue debt, the central government debt is likely to underestimate the public-sector liabilities.

${ }^{9}$ According to the Handbook of Securities Statistics (BIS, European Central Bank, IMF, 2009), a security is a negotiable financial instrument whose legal ownership is transferable from one owner to another by delivery or endorse-
} 
Our domestic public debt dataset comprises 40 low and lower-middle-income countries over the period 1971-2011 (see Table A1 in Appendix). ${ }^{11}$ Following the GFSM (IMF, 2001), we adopt the residency basis to define domestic debt in 35 countries, whereas the currency basis is used in 5 countries because of their debt recording practices and data constraints. We include all domestic financial liabilities defined by the GFSM (IMF, 2001), with the exception of arrears, and focus on the Central Government debt as most other studies in the literature. ${ }^{12}$ As a novelty, our dataset contains information on the level and structure of domestic public debt: along with the stock of domestic public debt, we gather data on on-budget interest payments, type of instruments, maturity, and investor base. ${ }^{13}$

Amongst the 40 countries, 33 are classified as LICs and 7 as lower-middle income countries. There are 38 countries benefiting from IDA lending (denoted IDA-only countries) and 2 receiving a mix of IDA and IBRD lending (denoted blend countries). HIPCs are two-thirds of the sampled countries. In terms of geographic location, 29 countries are in Sub-Sahara Africa, 5 in East Asia and Pacific, 2 in Europe and Central Asia, 2 in South Asia, one in Latin America and the Caribbean, and one in Middle East and North Africa.

As expected when dealing with LICs, the data availability is quite heterogeneous across countries and over time. In our dataset, accurate information on debt stock exists for 40 countries whereas data on debt structure is reported for 36 countries. In addition, the time span of variables included in the dataset largely differs across countries. We are therefore constrained to selectively choose panels of data to conduct meaningful descriptive analyses and comparisons in Section 4. Thus, we construct two balanced panels covering the period 1996-2011: the Debt Stock Sample contains the domestic debt stock series for 21 countries, and the Debt Structure Sample includes data on debt stock and structure for 15 countries. We also construct a balanced panel covering the period 2007-2011 for the whole sample of 36 countries, the Debt Structure Short Sample.

In the next section, we illustrate the evolution of domestic public debt in LICs using the Debt Stock Sample and we analyze the debt structure and financing terms - including on-budget interest payments, type of instruments, maturity, and investor base - using the Debt Structure Sample and the Debt Structure Short Sample. Reported time series are primarily weighted coun-

ment. A security is designed to be traded on an organized exchange, although actual trading in secondary markets may not happen.

${ }^{10}$ The treatment of government (financial, liquid) assets that leads to the definition of gross versus net debt is becoming an important issue in EMs. However, just a few LICs provide data on net debt and stocks of financial liquid assets that could potentially be used to repay maturing debt.

${ }^{11}$ Lower-middle-income countries included in our database slightly exceed the per-capita GNI threshold separating their income category from the low-income countries.

${ }^{12}$ Reporting of arrears varies largely across countries, e.g., the timing of recording could be as soon as payments are delayed, or when arrears are audited, or when they are settled or securitized. Information on debt owed by subnational governments and state-owned enterprises is available for only 7 countries in a few recent years, thus preventing us from constructing a Public Sector debt dataset.

${ }^{13}$ Our data sources concerning domestic public debt include IMF Staff Reports, websites of countries' Ministry of Finance and Central Bank, and consultations with World Bank country economists, IMF country desks, and debt managers members of a network established by the World Bank's Economic Policy, Debt, and Trade Department. Data on external public debt are drawn from the World Bank's Debt Reporting System (DRS). 
try averages, with the GDP in dollars at constant 2005 prices as weight. We complement the average figures with box-plot analysis to assess the data variability across countries in both datasets.

\section{Characteristic of Domestic Public Debt in LICs}

\subsection{Evolution of domestic debt}

Figure 1 shows the evolution of Central Government debt for the Debt Stock Sample in 19962011. On average, LIC external debt is much lower than in the past, decreasing from 72 percent of GDP in 1996 to 23 percent in 2011, whereas LIC domestic debt is on the rise, increasing from 12.3 percent of GDP to 16.2 percent. Both HIPCs and non-HIPCs managed to reduce the burden of foreign liabilities, particularly the HIPCs benefiting from debt relief initiatives that largely wrote off their financial obligations to official creditors. Trends concerning the domestic public debt, on the other hand, differ between HIPCs and non-HIPCs since the early 2000: HIPCs have reduced domestic debt since the peak of 20 percent of GDP in 2002, while non-HIPCs have increased it from 12 percent of GDP to 18 percent in the period 2000-2011. Overall, LICs now hold a public debt portfolio with a fairly balanced composition in terms of domestic and external liabilities compared to the past. In both HIPCs and non-HIPCs, the public domestic debt represented 40 percent of the total public debt in 2011, almost three times the share observed in 1996. $^{14}$

LICs are quite heterogeneous with regard to reliance on domestic debt, as the box-plot in Figure 1 and the Table A2 in Appendix suggest. For instance, Cambodia has virtually no domestic liabilities and Eritrea has an amount almost equal to its GDP. Most LICs have increased the stock of domestic debt (relative to GDP) since the mid-1990s, but there are exceptions such as Ethiopia, Rwanda, Solomon Islands, and Tanzania, whose level of domestic debt decreased. We do not find evidence of LICs uniformly substituting domestic debt for external debt (or viceversa): the pairwise correlations between the ratios of domestic and external debt to GDP in 19962011 for each individual LIC, have a positive sign in some countries and a negative sign in others. Country-specific circumstances may then play a role in the pattern of substitution (if any) between local and foreign financing in LICs.

\footnotetext{
14 Arnone and Presbitero (2010) argue that the share of domestic debt drastically increased in HIPCs soon after receiving external debt relief. But the share slightly decreased since 2006, possibly because HIPCs re-engage in securing foreign financing to take advantage of the new borrowing space created by the debt relief and the lower global interest rates. A scaling-up of public investment projects has been observed in some HIPCs (Arnone and Presbitero, 2010).
} 
Figure 1: Domestic and External Debt (percentage, weighted average)
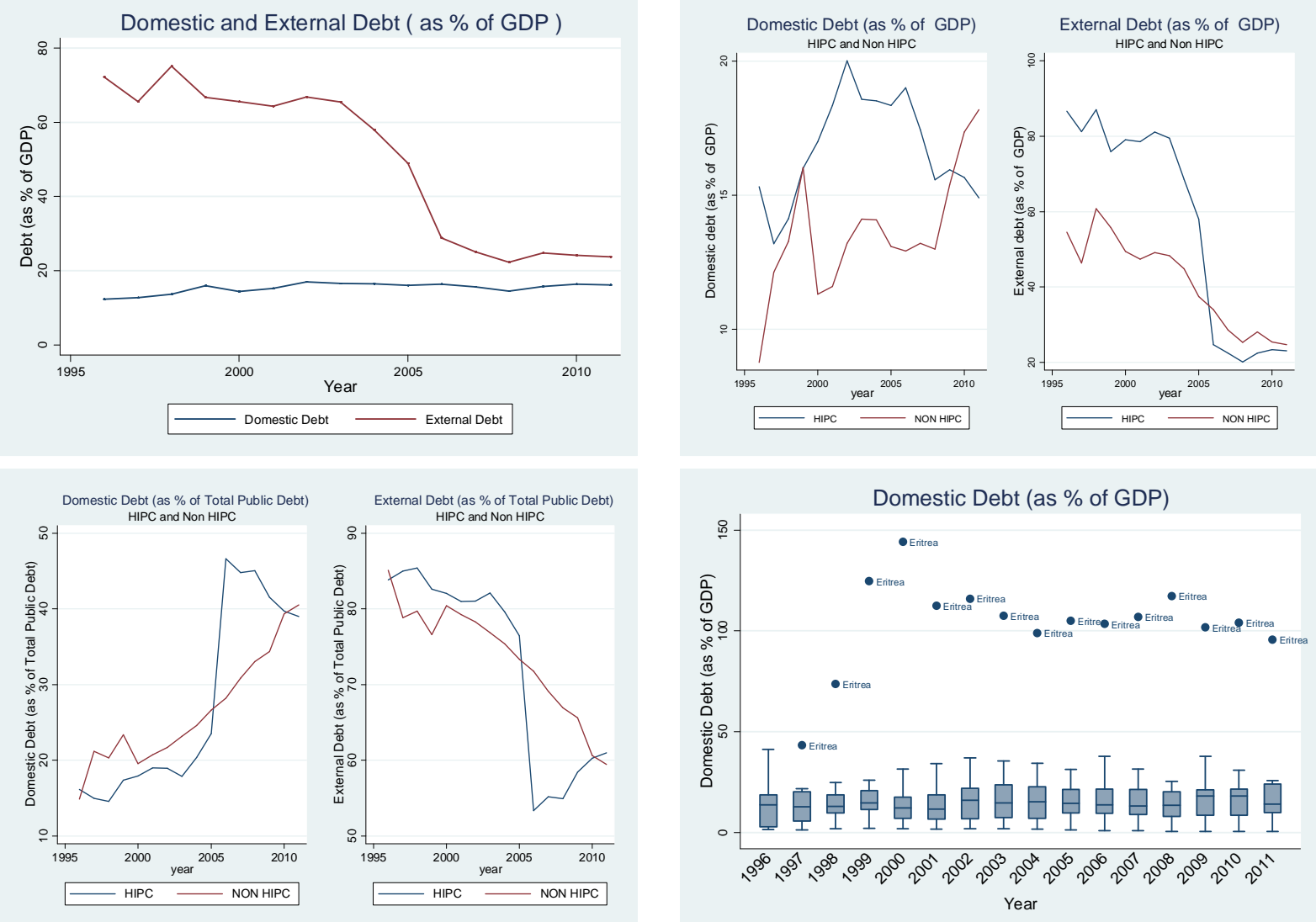

Source: our elaboration on the LIC domestic public debt dataset.

\subsection{Financial cost and burden}

A main concern about domestic debt relates to its financial cost and burden relative to external debt. For the Debt Structure Sample in 1996-2011, Figure 2 displays implicit interest rates as proxies of borrowing cost. The nominal implicit interest rate is calculated as the interest payments in the current year divided by the average debt stock in the current and preceding year. ${ }^{15}$ For the domestic debt, we calculate the real implicit interest rate by subtracting the GDP deflator inflation from the nominal rate. For the external debt, we add the average depreciation rate of the local currency against the US dollar and SDR in order to capture losses (or gains) resulting from exchange rate fluctuations in the presence of foreign currency-denominated external debt. On average, the cost of external borrowing never exceeded 4 percent per annum and has been always much cheaper than the nominal cost of domestic borrowing, even including the currency depreciation losses. The domestic nominal implicit interest rate, however, declined significantly from 18 percent per annum in 1996 to 8 percent in 2011. On average, the real cost of domestic borrowing is also lower than in the past and quite often the real implicit interest rates are negative

\footnotetext{
${ }^{15}$ Our choice of using the average debt stock as denominator is justified by the large share of short-term liabilities in the domestic debt that accrue interests the same year in which they are issued. Other studies use the current debt stock as denominator (Christensen, 2005) or the previous debt stock (Arnone and Presbitero, 2010).
} 
and thus encourage borrowing from local sources. Both HIPCs and non-HIPCs achieved lower nominal borrowing costs in recent years. The domestic implicit interest rate is slightly lower in HIPCs as they rely more on advances from the Central Bank, which are relatively inexpensive vis-à-vis other sources of domestic financing.

Figure 2 also shows simple measures of the financial burden of public debt in LICs: the interest payments on domestic debt, and the interest payments on external debt plus the valuation effect induced by exchange rate fluctuations. By construction, the financial burden of a given type of debt mechanically combines its implicit interest rate (i.e., borrowing cost), its share in the total public debt (weight), and the size of the public debt (volume). As a consequence of the large reduction in foreign liabilities relative to GDP and the stability of external borrowing cost, the burden of external debt in LICs fell from nearly 2.2 percent of GDP in the late 1990s to 0.3 percent in recent years. LICs also experienced a mild drop in the burden of domestic debt from 1.7 percent of GDP to 1.3 percent, driven instead by a cheaper domestic borrowing cost.

On average, therefore, LICs currently face a heavier burden stemming to domestic liabilities compared to foreign liabilities. But the cross-country heterogeneity observed earlier with regard to reliance on domestic borrowing leads also to variations in the associated financial burden. For instance, in 2011 Malawi and Kenya afforded domestic interest payment around 3 percent of GDP, whereas Guinea-Bissau, Rwanda, and Togo paid less than 0.5 percent. More generally, we found a different pattern between HIPCs and non-HIPCs, with the former benefiting, since 2005, from a much larger reduction in the domestic interest bill than non-HIPCs. Given that the stock of domestic debt was not extremely different in the two groups (Figure 1), the lower cost of domestic debt in HIPCs may be a side effect of debt relief programs, which could have fostered local financial development and brought down borrowing costs. In addition, the HIPCs took advantage of external debt relief and, after 2000, the share of interest payments on external debt quickly converged to the low values of non-HIPCs. 
Figure 2: Cost of Domestic and External Borrowing (percentage, weighted average)
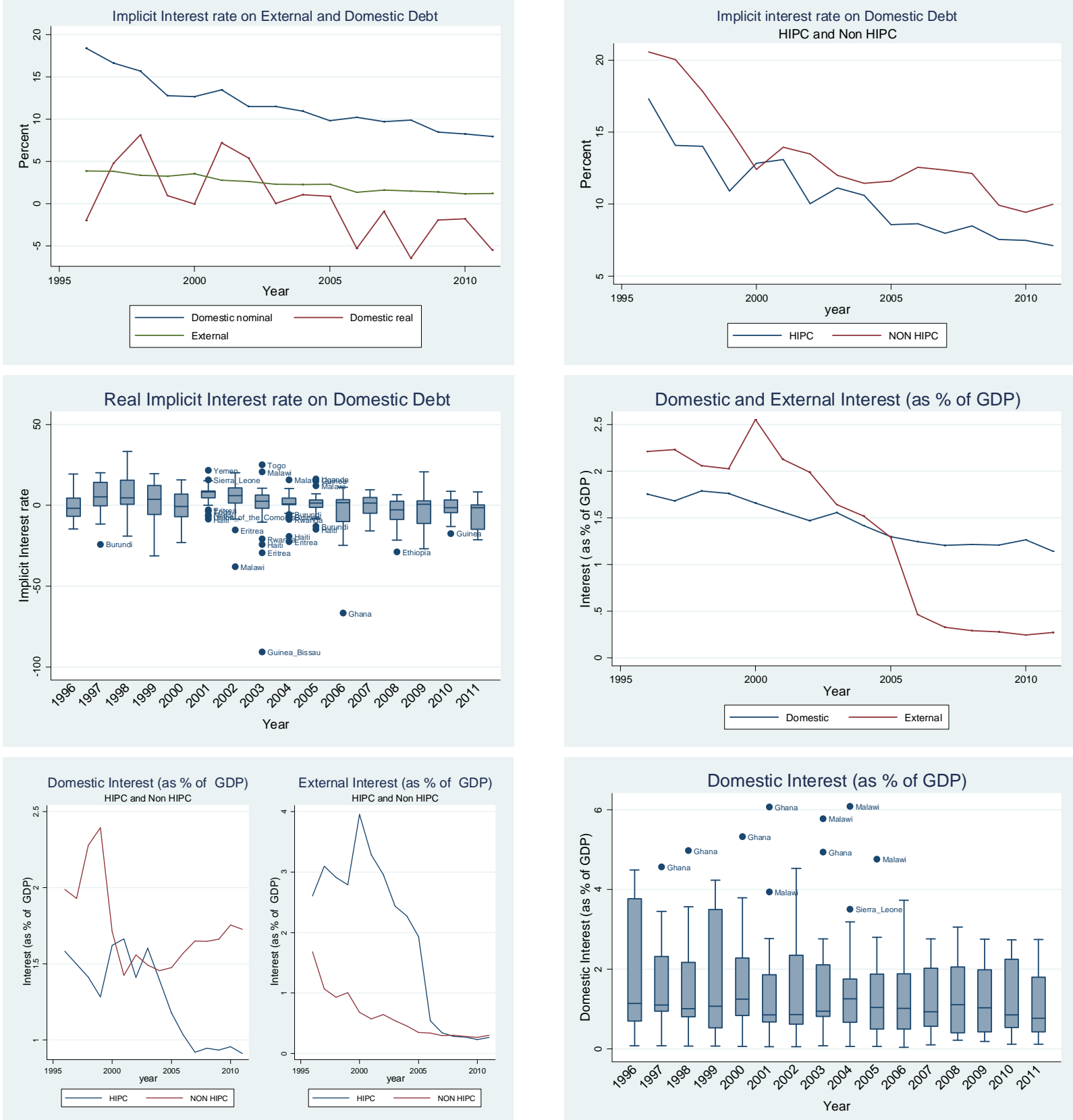

Source: our elaboration on the LIC domestic public debt dataset.

\subsection{Instruments}

The structure of domestic public debt in terms of type of instruments matters. According to $\mathrm{Ab}-$ bas and Christensen (2010), the development of local government debt markets helps supply a benchmark yield curve for private lending contracts as well as financial instruments that serve as saving assets and collateral vehicles. But these benefits are to be expected from government debt 
instrumented through securities, not from government debt issued in captive markets or liabilities associated with arrears and overdrafts.

For the Debt Structure Sample in 1996-2011, Figure 3 shows the composition of the domestic public debt portfolio in terms of major instruments defined by the GFSM (IMF, 2001), namely loans, securities, other accounts payable (e.g., Central Bank advances), insurance technical reserves, and currency and deposits (e.g., judiciary deposits). Securities and Central Bank advances to the Treasury are the main sources of domestic financing in LICs. On average, since the early 2000s securities constitute three-quarters of domestic debt whereas Central Bank advances are nearly one-fifth. The breakdown in HIPCs and non-HIPCs reveals a remarkable difference in the structure of government debt: the share of securities is much higher in non-HIPCs and, conversely, the share of Central Bank advances is larger in HIPCs (possibly because their markets are relatively less developed and the pressures of fiscal dominance and debt monetization are more acute). Interestingly, we find out an upsurge of Central Bank advances in response to the financial crisis in both groups.

The box-plot in Figure 3 and the Table A2 in Appendix show differences across individual countries. On average, Kenya, Ghana, and Tanzania issue securities exclusively, in contrast to Guinea-Bissau, Haiti, Guinea, and Burundi, in which securities are a small share of the domestic public debt.

\section{Figure 3: Domestic Debt by Type of Instrument (percentage, weighted average)}
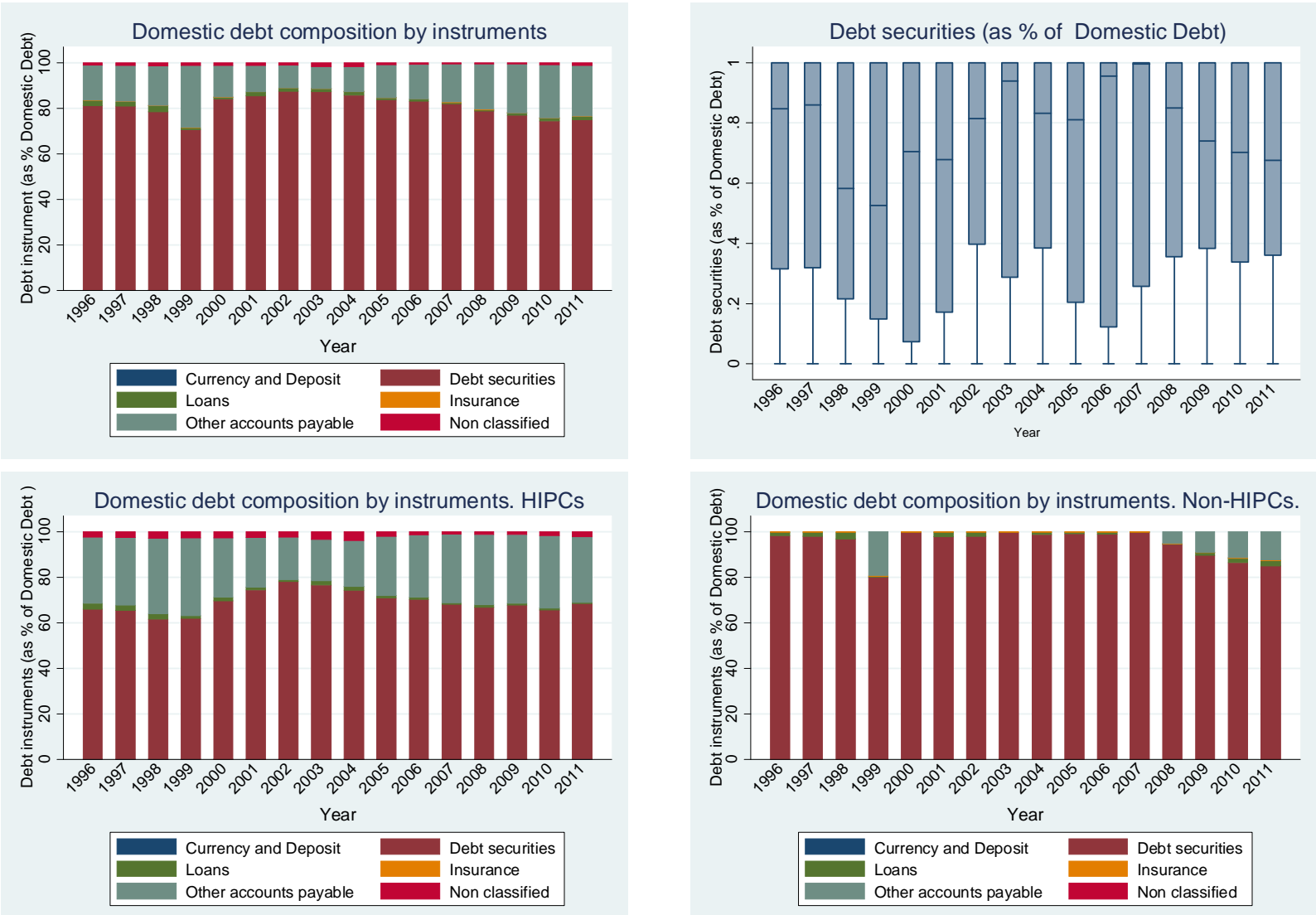

Source: our elaboration on the LIC domestic public debt dataset. 


\subsection{Maturity}

A common presumption about the choice between domestic and external debt is that a government faces a tradeoff concerning maturity and currency mismatch: domestic debt is often denominated in local currency but of shorter maturity relative to external debt. In fact, many developing countries are unable (or unwilling) to issue long-term government securities in local financial markets at a reasonable interest rate (Panizza, 2008; Hausmann and Panizza, 2003; Mehl and Reynaud, 2005).

The relative share of long- and short-term domestic debt instruments could be explained by either demand or supply factors. The government may hesitate to issue long-term debt if the yields curve is sufficiently upward-sloped, so that borrowing costs increase with tenors. However, even if the government recognizes the benefit of extending the maturity profile, supply-driven factors may limit its ability to do so. In a volatile macroeconomic environment, the market might be not ready or willing to absorb long-term government debt in view of significant inflation and default risks (Christensen, 2005). Moreover, the banking system, which often dominates the government debt market in LICs, generally has a strong incentive for buying T-bills, given that these instruments provide a regular flow of earnings and have a privileged treatment (e.g., a zero credit risk) in the calculation of risk-based capital adequacy requirements (Diouf and Dufrense, 2012). An investor base lacking mutual funds, pension funds, and insurance companies, all institutions that typically have long-term investment horizons, hampers the possibility of extending the maturity of public debt. In this regard, it is a well-established principle that the maturity profile's length can be viewed as a measure of the degree of market development.

For the Debt Structure Sample in 1996-2011, Figure 4 displays the composition of the domestic public debt portfolio in terms of maturity. Long-term (short-term) debt has original maturity of more (less) than one year at the date of issuance. In the first panel, we treat Central Bank advances as long-term liabilities because in practice they are not callable and can be safely assumed to be rolled over on a continuous basis (even advances that are technically short-term instruments). In the second panel, we exclude Central Bank advances altogether from the series of domestic debt and re-calculate the maturity composition. On average, LICs have managed to lengthen their domestic public debt portfolio, with the share of long-term liabilities in the total domestic debt increasing from 52 percent to 67 percent in 1996-2011. The maturity lengthening persists even if Central Bank advances are excluded. Differentiating between HIPCs and nonHIPCs suggests that the overall increase in the share of long-term has been driven solely by the later. HIPCs, by contrast, had a relatively larger share but it has remained quite stable since the mid-1990s. Table A2 in Appendix shows similar figures for individual countries. 
Figure 4: Domestic Debt by Maturity (percentage, weighted average)
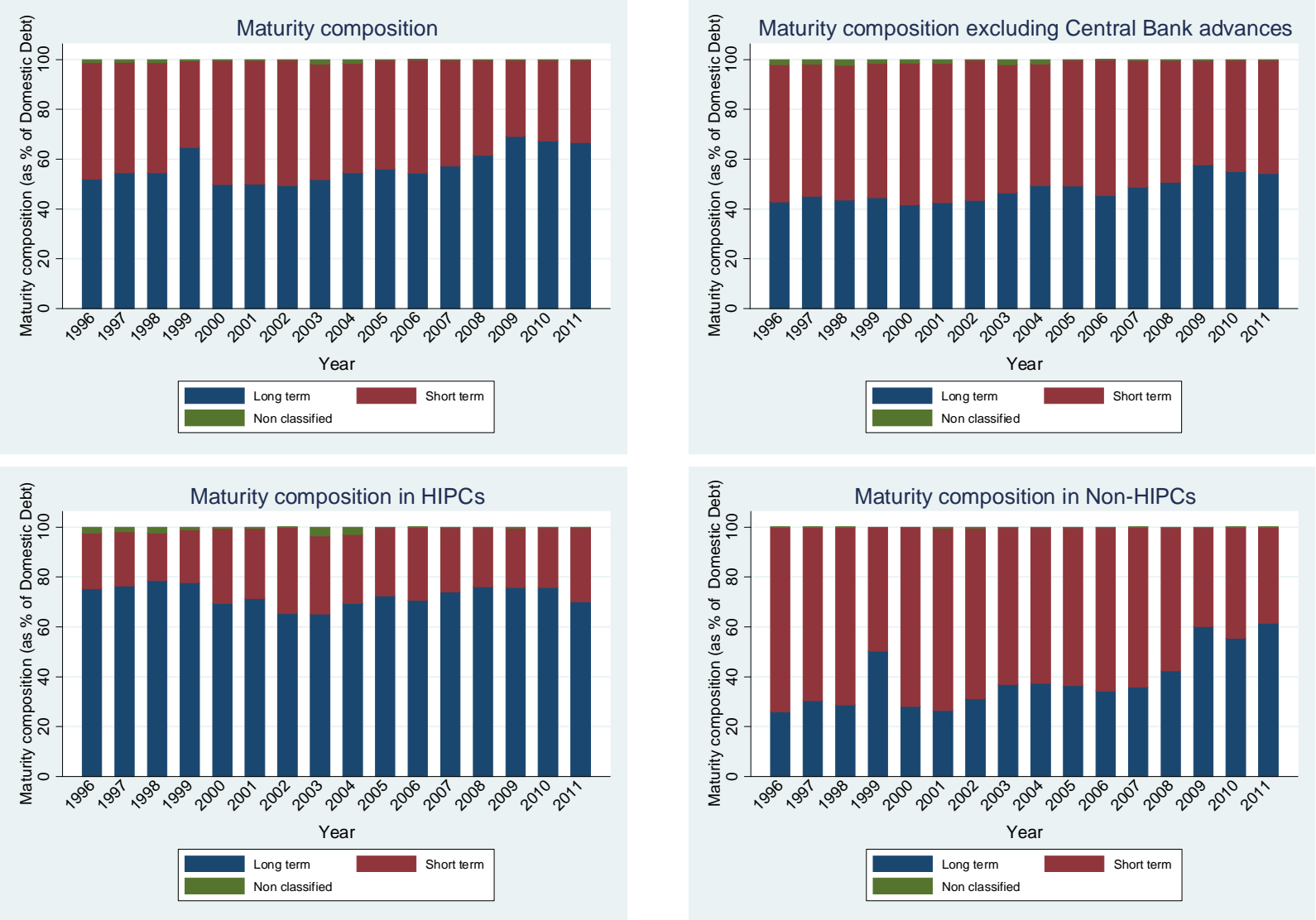

Source: our elaboration on the LIC domestic public debt dataset.

\subsection{Investor base}

Investors in LIC government debt are few is nature and often also in number. Domestic public debt instruments are held primarily by commercial banks, the Central Bank, financial institutions in the non-banking system (e.g., mutual funds, pension funds, and insurance companies), and non-financial institutions (e.g., non-financial corporations and individual investors). The investor base in local financial markets is typically narrow and highly concentrated (Arnone and Presbitero, 2010).

Previous studies underlie the benefits of a diverse investor base in terms of lowering borrowing costs as well as reducing market yield volatility. Broadening the investor base attenuates the monopoly power of a particular group of financial institutions, bringing down interest rates and rollover risks (Christensen, 2005). Larger crowding out effects are to be expected when the investor base is strongly biased towards commercial banks. As indicated above, the banking system generally has a strong incentive for buying government debt and seeking profitability in lending to the public sector. This may lead to relatively weaker incentives to extend credit to riskier private borrowers and even lower efficiency in banking operations and financial intermediation (Hauner, 2006). Crowding out effects are especially harmful in LICs because small- and 
medium-sized private companies heavily rely on bank financing, with negligible (if any) opportunities in corporate bond and stock markets.

Other potential distortions in the incentives facing financial institutions that invest in government debt. First, banks are more likely to prefer a short-term portfolio allocation, thus raising rollover risk for the government. Second, domestic banks and institutional investors may be induced by moral suasion to absorb excessive public debt, which may amplify the deleterious effect of a debt crisis in case the government is following unsustainable policies (Panizza, 2008). Third, a large bank exposure to government securities could undermine the solvency of financial institutions in times of economic distress, potentially leading to a systematic banking crisis (Diouf and Dufrense, 2012). Distortions also arise when it is the Central Bank that finances the government's short-term cash imbalances through overdraft facilities for managing daily transactions and cover unexpected shortfalls in revenue (Johnson, 2001). A higher independence of the Central Bank helps lowering the leverage of the government in borrowing though these facilities.

For the Debt Structure Sample in 1996-2011, Figure 5 shows the participation of investors holding the domestic public debt. On average, the banking system comprising commercial banks and the Central Bank holds nearly three-quarters of the domestic liabilities, with a quite stable participation. Within the banking system, the share of commercial banks has increased since the early 2000s. The breakdown into HIPCs and non-HIPCs reveals that the former rely much more on Central Bank lending (e.g., advances) whereas the later tap commercial banks and other market investors. 
Figure 5: Domestic Debt by Holder (percentage, weighted average). HIPCs (bottom left panel) and non-HIPCs (bottom right panel)
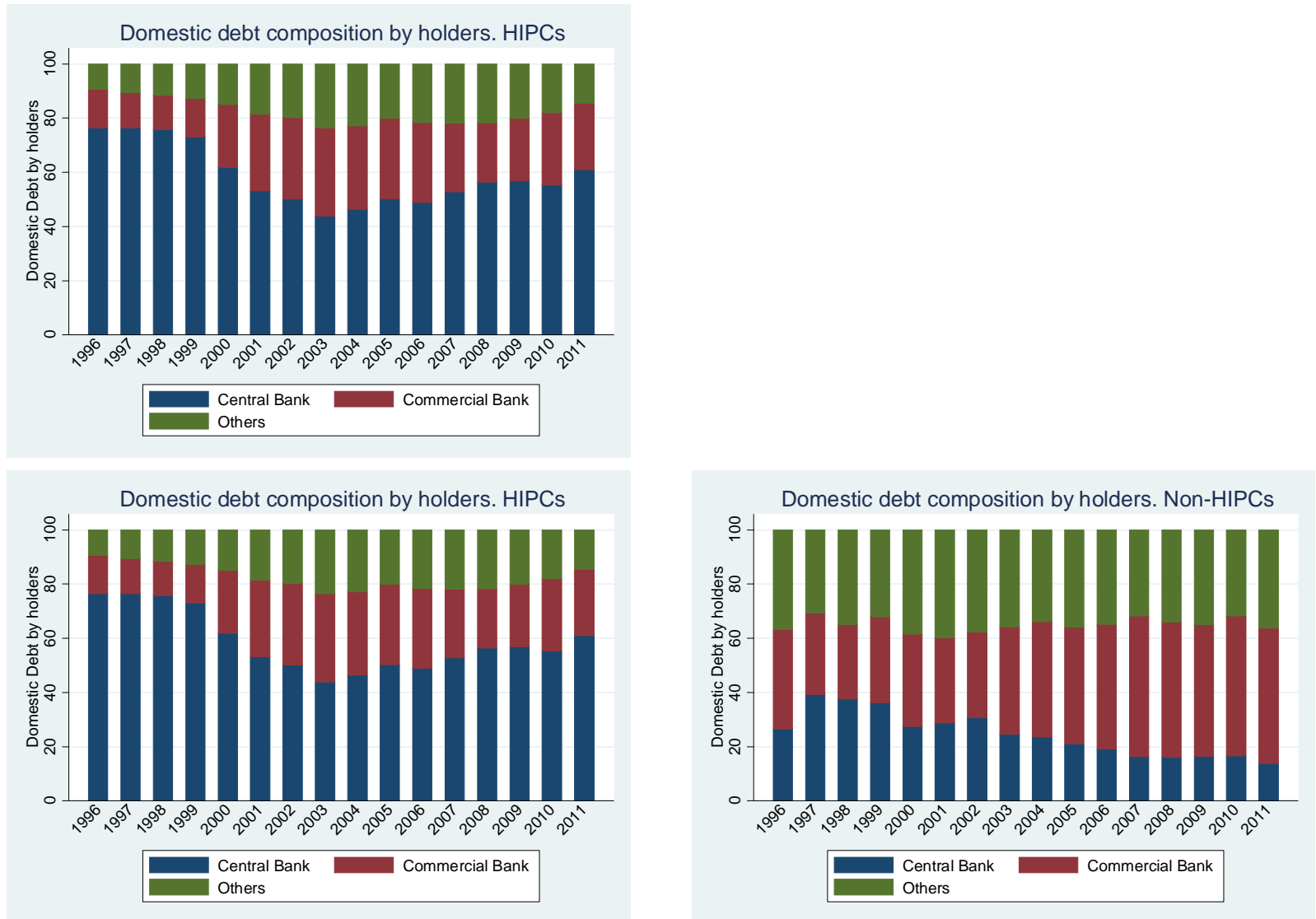

Source: our elaboration on the LIC domestic public debt dataset.

\subsection{Relationships between cost of domestic debt, maturity, and investor base}

Using the Debt Structure Short Sample, which can be seen as a constellation of domestic public debt portfolios for 36 countries in recent years, the casual inspection of simple correlations provides preliminary evidence on the relationships between cost of domestic debt, maturity, and investor base.

Figure 6 (left panel) shows observed pairs of cost of domestic public debt (proxied with the implicit interest rate) and the share of long-term instruments. The simple correlation between the two variables is -0.31 and statistically significant, suggesting that debt portfolios of longer maturity face lower cost than debt portfolios of shorter maturity. This finding is at odds with the common perception that LICs are unable to issue long-term liabilities at a reasonable interest rate in domestic financial markets. Admittedly, the observations include countries (mostly HIPCs) where a large share of public domestic debt is held by the Central Bank, who often lends long and cheap. Excluding the observations where the Central Bank share exceeds 50 percent in the Figure 6 (right panel), the correlation goes to -0.15 (albeit not statistically significant) but it does not become positive, as that perception would imply. 
The negative correlation between the cost and the maturity of domestic debt would imply that only countries where the average cost of debt is low can afford to issue long-term (costlier) debt. Given that a low nominal implicit interest rate may reflect a more efficient market or a lower inflation rate, the inverse relationship between cost and maturity is consistent with countries with more developed domestic financial markets and better macroeconomic policies being able to issue longer term instruments at a lower cost. This suggests that some LICs are reaping the benefits of developing domestic financial markets and improving macroeconomic management. In fact, measuring the degree of financial development by the savings-to-GDP ratio and the ratio of credit to the private sector over GDP, we find that the correlation between the implicit interest rate and the share of long-term domestic debt is negative and significant for countries where the development of financial markets is above the median, and not significantly different from zero in countries with a low level of financial development. ${ }^{16}$

Figure 7 presents the relationship between the share of domestic public debt held by investors other than the Central Bank, the cost of domestic public debt (left panel) and the share of long-term instruments (right panel). A positive, statistically significant correlation (0.25) between the non-Central Bank holdings and the cost of debt is consistent with the view that LIC governments with larger reliance on commercial banks and other financial institutions as sources of local funding face higher financial costs on their domestic liabilities. On the other hand, a negative, statistically significant correlation (-0.33) between non-Central Bank holdings and the share of long-term instruments supports the view that those LIC governments also bear domestic liabilities of shorter maturity. This finding is consistent with a preference for short-term instruments by commercial banks, which in turn might lead to reflect supply-side limits to the issuance of long-term debt instruments (Diouf and Dufrense, 2012). Panizza (2008) highlights the associated rollover risk and macroeconomic vulnerability of such a short-term maturity profile.

Correlations identified in Figure 7 have the expected signs and are statistically significant. Yet LICs face quite heterogeneous financing terms even when they have similar shares of domestic public debt held by non-Central Bank investors. Figure 8 reports the distribution of proxy variables of financial cost and maturity of debt portfolios, distinguishing between three groups of portfolios: the groups 1,2, and 3 correspond, respectively, to debt portfolios whose share held by non-Central Bank investors is up to one-third, between one- and two-thirds, and more than two-thirds. Mean values of financial cost and maturity variables do vary across groups, but the overall distributions of these variables are quite disperse and tend to overlap between groups 2 and 3.

As a response to the global crisis in 2009, LICs were recommended to use their available fiscal space to implement countercyclical policy responses and support aggregate demand (IMF, 2010). Most LICs did not curtail spending despite of falling revenues, and those with much stronger pre-crisis macroeconomic policy buffers even accelerated the growth rate of real prima-

\footnotetext{
${ }^{16}$ Specifically, when using the savings-to-GDP ratio, the correlation between the implicit interest rate and the share of long-term debt is equal to -0.40 for countries in which the savings-to-GDP ratio is above the sample median and to -0.14 (non statistically significant) in countries where the ratio is below the media. The corresponding values when using the ratio of credit to the private sector over GDP are -0.36 (statistically significant) and 0.10 (non statistically significant).
} 
ry expenditures, including public investment. Budget deficits widened and LICs resorted to domestic and external financing to fill the gap. According to IMF (2010), more than half of the additional deficit was financed by domestic sources, including borrowing in local government debt markets, central bank financing, or drawing down government deposits. Figure 9 (upper panels) indicates that most LICs in our sample indeed increased their public debt relative to GDP between 2007 and 2011, and benefited from an implicit cost of domestic borrowing broadly unchanged. LICs whose share of domestic public debt held by non-Central Bank investors was up to one-half in 2007 tended to borrow more from them and so exhibit a higher share in 2011 (Figure 9, lower panels). In a sense, the anti-crisis response induced these LICs to rely more on previously untapped domestic sources of financing. On the other hand, LICs with the Central Bank holding relatively more government debt in 2007 did not have an homogeneous reaction, as some tended to borrow more from the monetary authority and others increased reliance on market investors. 
Figure 6: Implicit interest rate and maturity
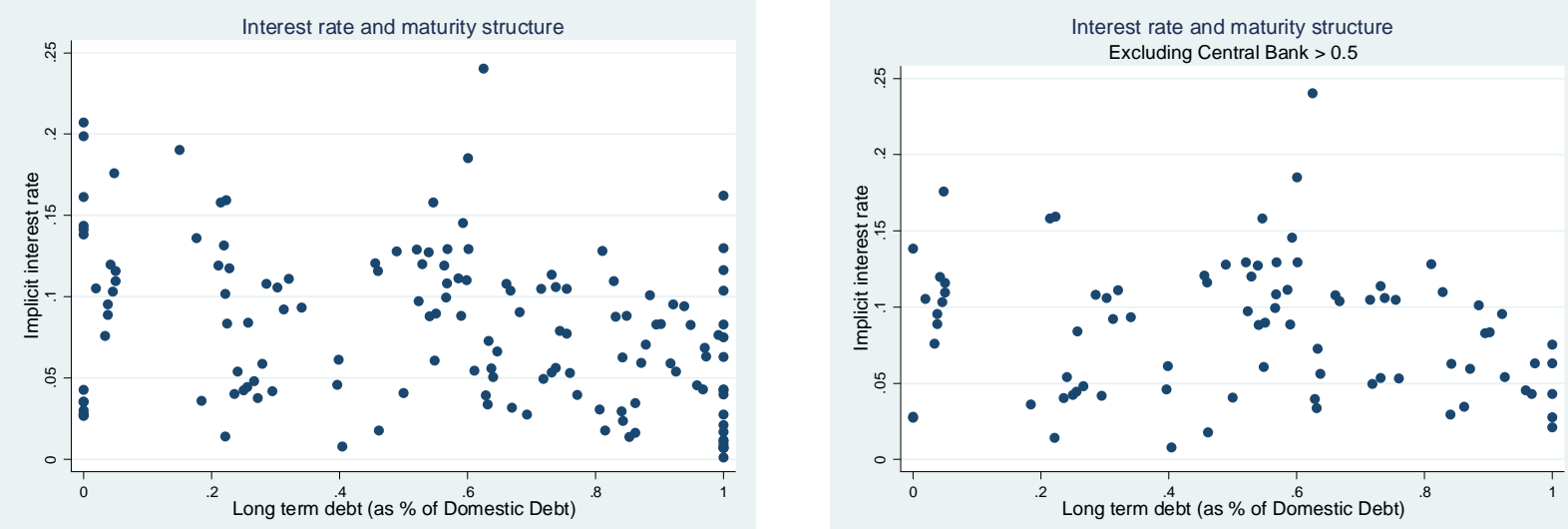

Source: our elaboration on the LIC domestic public debt dataset.

Note: Correlation is -0.31 in left panel (144 obs.) and -0.15 in right panel ( 85 obs.).

Figure 7: Implicit interest rate, maturity, and investor base
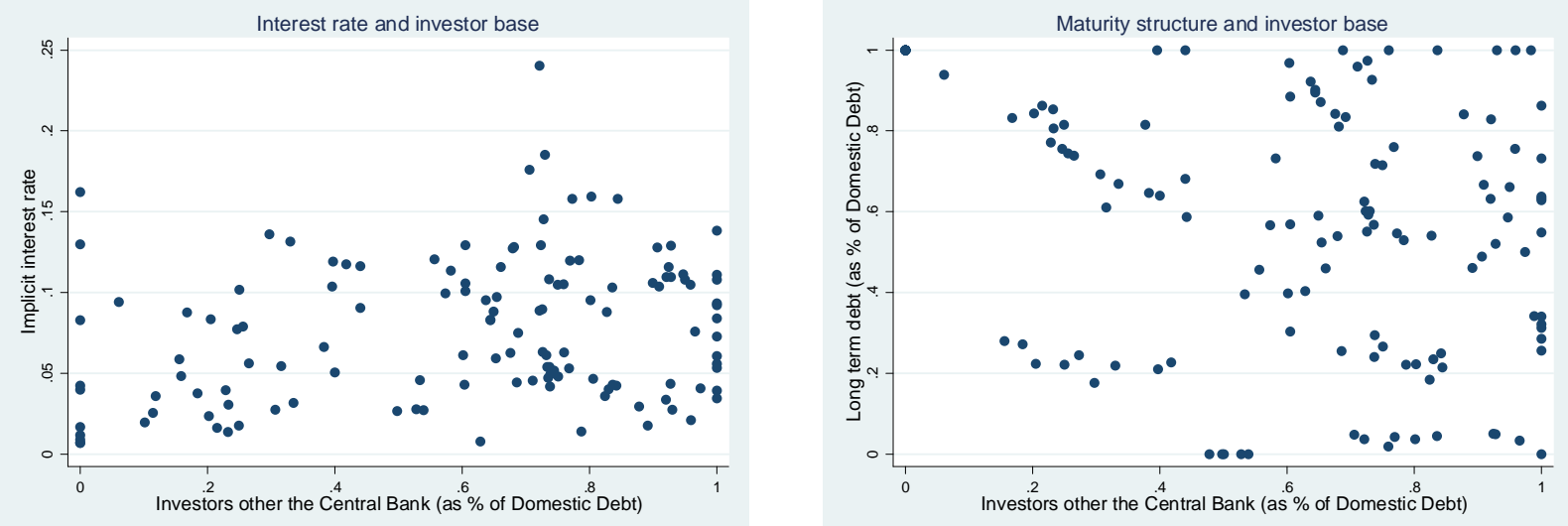

Source: our elaboration on the LIC domestic public debt dataset.

Note: Correlation is 0.25 in left panel (132 obs.) and -0.33 in right panel (133 obs.).

\section{Figure 8: Implicit interest rate, maturity, and investor base}
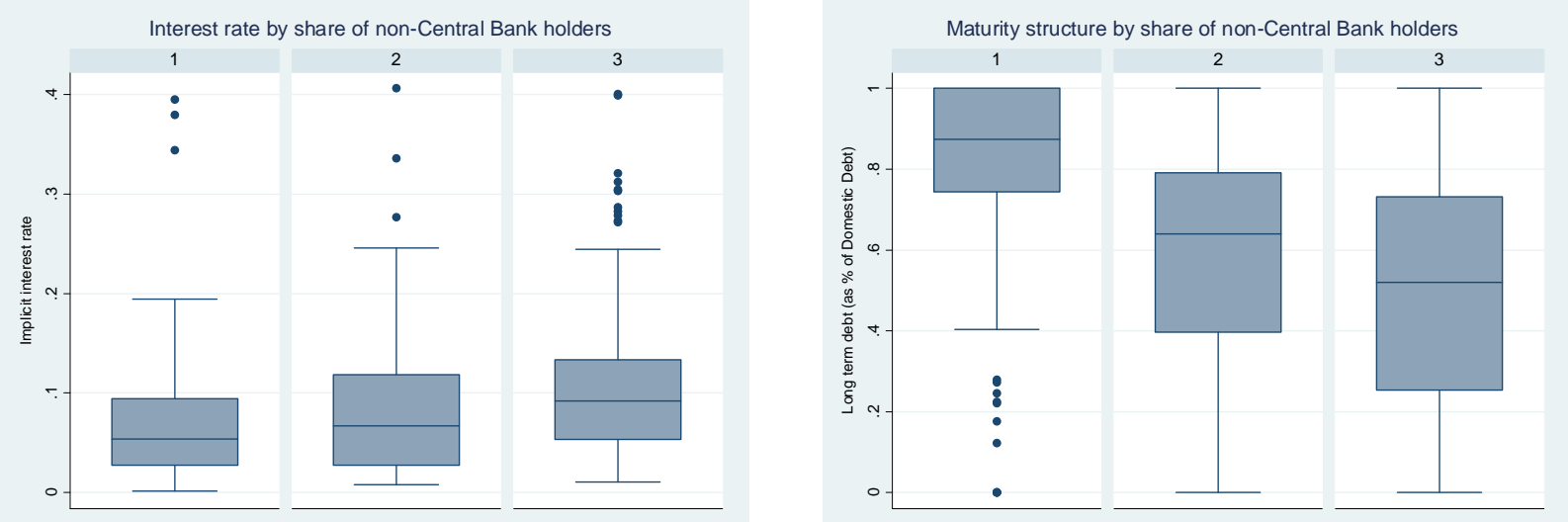

Source: our elaboration on the LIC domestic public debt dataset.

Note: Groups 1, 2, and 3 correspond, respectively, to debt portfolios whose share held by non-Central Bank investors is up to one-third, between one- and two-thirds, and more than two-thirds. 
Figure 9: Domestic Debt Level and Structure in 2007 and 2011.
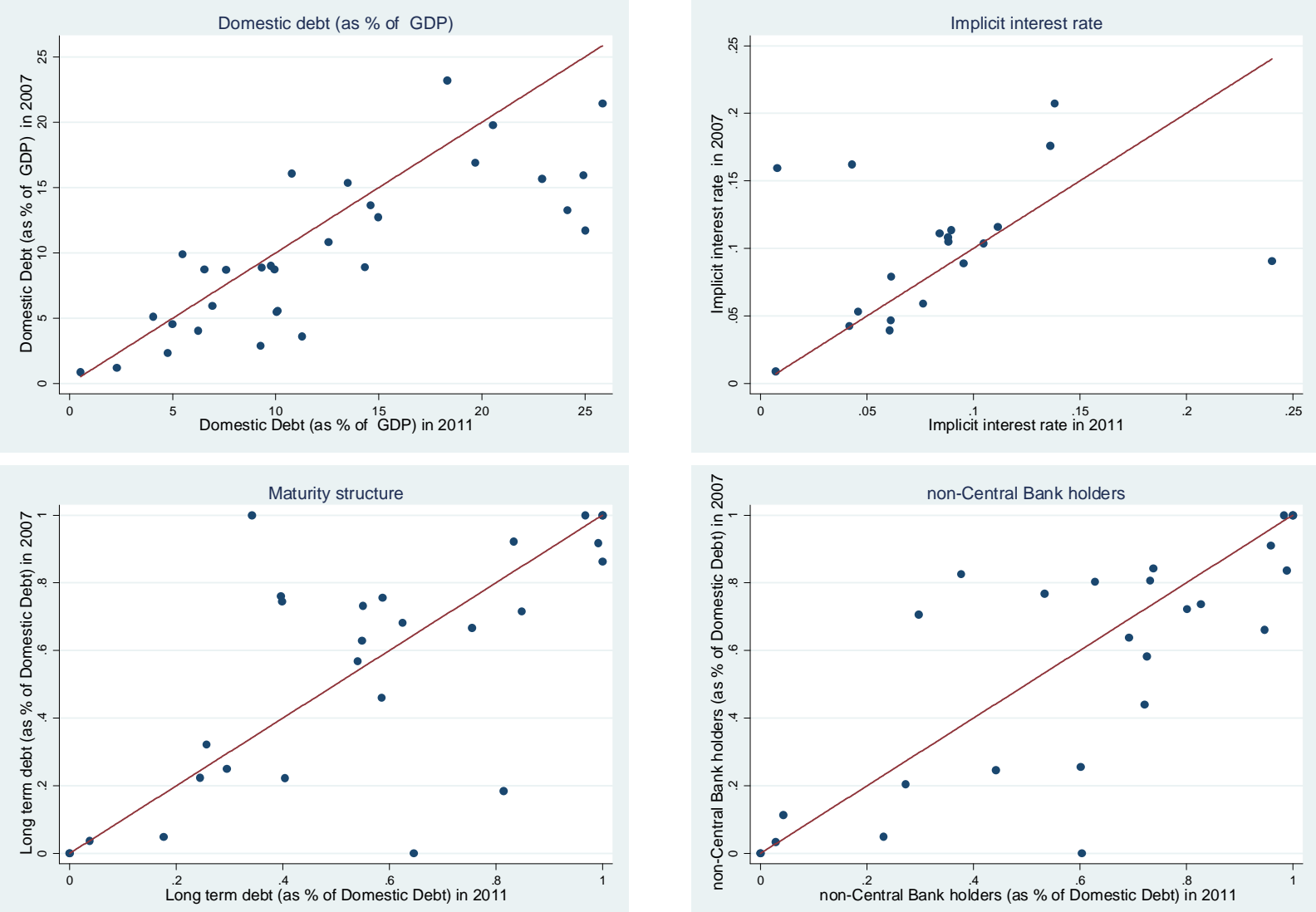

Source: our elaboration on the LIC domestic public debt dataset.

\section{Conclusions}

Several low-income countries are now taking advantage of lower debt burdens, thanks to the debt relief programs of the late 1990s and early 2000s. Since then, they started relying on a growing basis on internal financing. The change in the composition of financing sources, related also to decreasing foreign aid and increasing foreign direct investment and remittances, could have several implications for debt sustainability and for the scaling-up of public investment and poverty-reduction expenditures. In theory, domestic debt could bring several benefits to LICs, but it could also crowd out private investment and thus hinder the growth process. However, the existing empirical evidence on the balance of costs and benefits of domestic borrowing in LICs is quite scant.

One of the main limitations that institutions and researchers face when dealing with the macroeconomic effects of government financing in LICs is poor data quality. In particular, data on domestic debt in LICs have been so far quite heterogeneous in terms of definitions and coverage. This paper introduces a new dataset on the stock and structure of domestic debt in 40 LICs over the period 1971-2011. With respect to the existing datasets, this one puts together information on domestic debt in a way that ensures comparability across countries (definition of domes- 
tic debt, level of public sector, liabilities included) and it recollects up-to-date information on domestic debt composition (instruments, maturity structure and investor base). In particular, we have been able to build two balanced panels covering the period 1996-2011: one with data on domestic debt stock series for 21 countries, and the other including data also on domestic debt structure for 15 countries. In this way, we have been able to analyze the evolution of internal financing in poor countries in the last fifteen years with a certain granularity, as not has been done so far.

The descriptive analysis of the stock and structure of domestic public debt in LICs highlights some interesting patterns and identifies marked differences in the evolution and composition of government liabilities across countries, especially between HIPCs and non-HIPCs. First, domestic debt increased from 12.3 percent of GDP in 1996 to 16.2 percent of GDP in 2011, almost reaching the size of external debt. However, we do not find evidence that LICs uniformly substituted domestic debt for external debt. Second, the debt burden on domestic debt is higher that on external debt but it has decreased over time, consistently with lower borrowing costs due to financial deepening. Third, we find that LICs have been able to increase the share of long-term instruments over time. Maturity lengthening went together with a reduction in borrowing costs. This correlation is at odds with the common perception that LICs are unable to issue long-term liabilities at a reasonable interest rate, and it suggests that some LICs are reaping the benefits of developing domestic financial markets. Fourth, there is evidence of an increase in the share of securities in government debt, especially for non-HIPCs. However, Central Bank advances, still important for many HIPCs, increased in response to the global financial crisis. Finally, a source of concern is the concentrated investor base, mainly dominated by commercial banks and the Central Bank, which may crowd out lending to the private sector and undermine financial stability.

Our preliminary descriptive analysis provides some useful insights on the macroeconomic effects of domestic borrowing in LICs. However, we believe that further research is required and our data set could provide a useful source to better inspect the tradeoffs that governments in poor countries have to face when choosing how to finance public spending. One natural way to exploit this data set is to see how the size of domestic debt is correlated with the characteristic of the economy (e.g., financial development, institutional framework, access to international capital markets) and how the increase in domestic debt affects public debt sustainability in LICs. Ongoing research work at the World Bank addresses these issues. Second, we think that a relevant issue to explore is the extent to which increasing domestic debt affects bank lending to the private sector and possible crowds out investment. At the aggregate level, better data could help to identify the correlations between capital flows to developing countries, pointing out possible sources of vulnerability. 
Table A1. LIC Domestic Public Debt Dataset

\begin{tabular}{|c|c|c|c|c|c|c|c|c|c|c|c|c|}
\hline Country name & $\begin{array}{c}\text { Income } \\
\text { Group }\end{array}$ & $\underset{\text { (i) }}{\text { Region }}$ & $\begin{array}{l}\text { Lending } \\
\text { category }\end{array}$ & $\begin{array}{l}\text { Debt } \\
\text { Relief }\end{array}$ & $\begin{array}{c}\text { Domestic } \\
\text { debt stock } \\
\text { (ii) (iii) } \\
\text { (iv) }\end{array}$ & $\begin{array}{l}\text { Instrumen } \\
\text { ts }\end{array}$ & Maturity & $\begin{array}{c}\text { Investor } \\
\text { base }\end{array}$ & $\begin{array}{l}\text { Main data } \\
\text { source }\end{array}$ & $\begin{array}{c}\text { Debt } \\
\text { Stock } \\
\text { Sample }\end{array}$ & $\begin{array}{c}\text { Debt } \\
\text { Structure } \\
\text { Sample }\end{array}$ & $\begin{array}{c}\text { Debt } \\
\text { Structure } \\
\text { Short } \\
\text { Sample } \\
\end{array}$ \\
\hline Burundi & LIC & AFR & IDA & HIPC & $1971-2011$ & $1975-2011$ & $1975-2012$ & $1975-2013$ & Website & $\mathrm{x}$ & $\mathrm{x}$ & $\mathrm{x}$ \\
\hline Benin & LIC & AFR & IDA & HIPC & $2000-2012$ & $2000-2012$ & $2007-2012$ & $\mathrm{n} / \mathrm{a}$ & IMF & & & $\mathrm{x}$ \\
\hline Burkina Faso & LIC & AFR & IDA & HIPC & $2003-2011$ & $2003-2011$ & $2003-2011$ & $2003-2011$ & PRMED & & & $\mathrm{x}$ \\
\hline Bangladesh & LIC & SA & IDA & & $1998-2011$ & $1998-2011$ & $1998-2011$ & $1998-2011$ & IMF & & & $\mathrm{x}$ \\
\hline CAR & LIC & AFR & IDA & HIPC & $2002-2011$ & $2002-2011$ & $2002-2011$ & $2002-2011$ & IFS $(v)$ & & & $\mathrm{x}$ \\
\hline Comoros & LIC & AFR & IDA & HIPC & $1982-2011$ & $\mathrm{n} / \mathbf{a}$ & $n / a$ & $\mathrm{n} / \mathbf{a}$ & IFS (vi) & $\mathrm{x}$ & & $\mathrm{x}$ \\
\hline Eritrea & LIC & AFR & IDA & HIPC & $1995-2008$ & $1995-2010$ & $1995-2010$ & $1995-2010$ & IFS (vii) & $\mathrm{x}$ & & $\mathrm{x}$ \\
\hline Ethiopia & LIC & AFR & IDA & HIPC & $1988-2010$ & $1988-2010$ & $1988-2010$ & $1988-2010$ & PRMED & $\mathrm{x}$ & $\mathrm{x}$ & $\mathrm{x}$ \\
\hline Ghana & LMIC & AFR & IDA & HIPC & $1981-2011$ & $1982-2011$ & $1981-2011$ & $1996-2011$ & Website & $\mathrm{x}$ & $\mathrm{x}$ & $\mathrm{x}$ \\
\hline Guinea & LIC & AFR & IDA & HIPC & $1995-2011$ & $1995-2011$ & $1995-2011$ & $1995-2011$ & IMF & $\mathrm{x}$ & $\mathrm{x}$ & $\mathrm{x}$ \\
\hline The Gambia & LIC & AFR & IDA & HIPC & $2005-2010$ & $2005-2010$ & $2005-2010$ & $2005-2010$ & Website & & & $\mathrm{x}$ \\
\hline Guinea Bissau & LIC & AFR & IDA & HIPC & $1995-2011$ & $1995-2011$ & $1995-2011$ & $1995-2011$ & IMF & $\mathrm{x}$ & $\mathrm{x}$ & $\mathrm{x}$ \\
\hline Haiti & LIC & LAC & IDA & HIPC & $1996-2010$ & $1996-2010$ & $1996-2010$ & $1996-2010$ & PRMED & $\mathrm{x}$ & $\mathrm{x}$ & $\mathrm{x}$ \\
\hline Kenya & LIC & AFR & IDA & & $1977-2011$ & $1977-2010$ & $1982-2010$ & $1977-2010$ & Website & $\mathrm{x}$ & $\mathrm{x}$ & $\mathrm{x}$ \\
\hline Kyrgyz & LIC & ECA & IDA & & $1996-2011$ & $1996-2011$ & $1996-2011$ & $1996-2011$ & IMF & $\mathrm{x}$ & $\mathrm{x}$ & $\mathrm{x}$ \\
\hline Cambodia & LIC & EAP & IDA & & $1993-2011$ & $\mathrm{n} / \mathrm{a}$ & $\mathrm{n} / \mathrm{a}$ & $1993-2011$ & IFS & $\mathrm{x}$ & & $\mathrm{x}$ \\
\hline Lao PDR & LMIC & EAP & IDA & & $2006-2011$ & $n / a$ & $\mathrm{n} / \mathrm{a}$ & $\mathrm{n} / \mathrm{a}$ & IMF & & & \\
\hline Liberia & LIC & AFR & IDA & HIPC & $2003-2011$ & $2006-2011$ & $2006-2011$ & $2006-2011$ & PRMED & & & \\
\hline Madagascar & LIC & AFR & IDA & HIPC & $1998-2011$ & $1998-2011$ & $1998-2011$ & $1998-2011$ & IMF & & & $\mathrm{x}$ \\
\hline Mali & LIC & AFR & IDA & HIPC & $2008-2011$ & $2000-2011$ & $2000-2011$ & $2000-2011$ & IMF & & & $\mathrm{x}$ \\
\hline Myanmar & LIC & EAP & IDA & & $1989-2011$ & $\mathrm{n} / \mathrm{a}$ & $n / a$ & $1989-2011$ & IFS & $\mathrm{x}$ & & $\mathrm{x}$ \\
\hline Mozambique & LIC & AFR & IDA & HIPC & $1999-2011$ & $1999-2011$ & $1999-2011$ & $1999-2011$ & PRMED & & & $\mathrm{x}$ \\
\hline Mauritania & LIC & AFR & IDA & HIPC & $2005-2011$ & $2005-2011$ & $2005-2011$ & $2005-2011$ & PRMED & & & $\mathrm{x}$ \\
\hline Malawi & LIC & AFR & IDA & HIPC & $1980-2011$ & $1980-2011$ & $1980-2011$ & $2002-2011$ & PRMED & $\mathrm{x}$ & $\mathrm{x}$ & $\mathrm{x}$ \\
\hline Niger & LIC & AFR & IDA & HIPC & $1998-2010$ & $n / a$ & $1998-2010$ & $n / a$ & PRMED & & & $\mathrm{x}$ \\
\hline Nepal & LIC & SA & IDA & & $1986-2011$ & $1986-2011$ & $1986-2011$ & $1986-2011$ & Website & $\mathrm{x}$ & $\mathrm{x}$ & $\mathrm{x}$ \\
\hline Rwanda & LIC & AFR & IDA & HIPC & $1981-2011$ & $1981-2011$ & $1981-2011$ & $1981-2011$ & Website & $\mathrm{x}$ & $\mathrm{x}$ & $\mathrm{x}$ \\
\hline Senegal & LMIC & AFR & IDA & HIPC & $2002-2011$ & $2002-2011$ & $2002-2011$ & $2002-2011$ & IMF & & & $\mathrm{x}$ \\
\hline Solomon Islands & LMIC & EAP & IDA & & $1980-2011$ & $1988-2011$ & $1988-2011$ & $1988-2011$ & Website & $\mathrm{x}$ & $\mathrm{x}$ & $\mathrm{x}$ \\
\hline Sierra Leone & LIC & AFR & IDA & HIPC & $1978-2011$ & $1978-2011$ & $1978-2011$ & $1978-2011$ & Website & $\mathrm{x}$ & $\mathrm{x}$ & $\mathrm{x}$ \\
\hline Chad & LIC & AFR & IDA & HIPC & $2005-2011$ & $2005-2011$ & $2005-2011$ & $2005-2011$ & IMF & & & $\mathrm{x}$ \\
\hline Togo & LIC & AFR & IDA & HIPC & $1975-2011$ & $\mathrm{n} / \mathrm{a}$ & $\mathrm{n} / \mathrm{a}$ & $1975-2011$ & IFS & $\mathrm{x}$ & & $\mathrm{x}$ \\
\hline Tajikistan & LIC & ECA & IDA & & $2001-2011$ & $2001-2011$ & $2001-2011$ & $2001-2011$ & IMF & 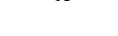 & & $\mathrm{x}$ \\
\hline Tanzania & LIC & AFR & IDA & HIPC & $1979-2011$ & $1981-2011$ & $1979-2011$ & $2000-2011$ & PRMED & $\mathrm{x}$ & $\mathrm{x}$ & $\mathrm{x}$ \\
\hline Uganda & LIC & AFR & IDA & HIPC & $1978-2011$ & $2002-2011$ & $1978-2011$ & $1978-2010$ & IMF & $\mathrm{x}$ & & $\mathrm{x}$ \\
\hline Vietnam & LMIC & EAP & Blend & & $2000-2011$ & $2000-2011$ & $2000-2011$ & $2000-2011$ & IMF & & & $\mathrm{x}$ \\
\hline Yemen & LMIC & MNA & IDA & & $1996-2011$ & 1996-2011 & 1996-2011 & $1996-2011$ & IMF & $\mathrm{x}$ & $\mathrm{x}$ & $\mathrm{x}$ \\
\hline Congo, Dem. & LIC & AFR & IDA & HIPC & $2006-2011$ & $n / a$ & $\mathrm{n} / \mathrm{a}$ & $n / a$ & IMF & & & \\
\hline Zambia & LMIC & AFR & IDA & HIPC & $1999-2011$ & $2002-2011$ & $2002-2011$ & $2002-2011$ & PRMED & & & $\mathrm{x}$ \\
\hline Zimbabwe & LIC & AFR & Blend & & 1981-2004 & 1981-2004 & 1981-2004 & $\mathrm{n} / \mathrm{a}$ & Web-IMF & & & \\
\hline
\end{tabular}

(i) Africa Region (AFR), East Asia \& Pacific Region (EAP), Europe \& Central Africa Region (ECA), Latin America \& Caribbean (LAC), Middle East and North A frica Region (MNA), South Asia (SA).
(ii) Domestic debt corresponds to Central Government, with the exception of Lao PDR (General Government), Niger (Public Sector), and Congo (iii) Domestic debt includes all financial liabilities defined by the GFSM (IMF, 2001), with the exception of Benin, Kenya, Kyrgyz, and Mauritania, whose definition includes only securities. For Benin and Mauritania, there are no data available for other liabilities. For Kenya and Kyrgyz, other liabilities are negligible and not reported. (v) Banking system is the only holder of domestic debt.

(vi) There is no domestic market. Central Bank is the only holder of domestic debt.

(vii) Banking system is the only holder of domestic debt. 
Table A2. LIC Domestic Public Debt Dataset - Debt Stock Sample and Debt Structure Sample

\begin{tabular}{|c|c|c|c|c|c|c|c|c|c|c|c|c|c|c|c|c|c|c|}
\hline Country name & $\begin{array}{l}\text { Debt } \\
\text { Relief }\end{array}$ & $\begin{array}{r}\text { Public } \\
\text { Debt in } \\
2011(\% \\
\text { of GDP) }\end{array}$ & $\begin{array}{l}\text { Domestic } \\
\text { Public } \\
\text { Debt in } \\
2011 \text { (\% } \\
\text { of GDP) }\end{array}$ & $\begin{array}{c}\text { External } \\
\text { Public } \\
\text { Debt in } \\
2011(\% \\
\text { of GDP) }\end{array}$ & $\begin{array}{c}\text { Variation } \\
\text { in Public } \\
\text { Debt/GDP } \\
\text { in 1996- } \\
2011 \text { (p.p.) }\end{array}$ & $\begin{array}{c}\text { Variation } \\
\text { in } \\
\text { Domestic } \\
\text { Public } \\
\text { Debt/GDP } \\
\text { in 1996- } \\
2011 \text { (p.p.) }\end{array}$ & $\begin{array}{c}\text { Variation } \\
\text { in External } \\
\text { Public } \\
\text { Debt/GDP } \\
\text { in 1996- } \\
2011 \text { (p.p.) }\end{array}$ & $\begin{array}{c}\text { Pairwise } \\
\text { correlatio } \\
\text { n between } \\
\text { External } \\
\text { Debt/GDP } \\
\text { and } \\
\text { Domestic } \\
\text { Debt/GDP } \\
\text { in 1996- } \\
2011 \\
\end{array}$ & $\begin{array}{l}\text { Securities } \\
\text { (\% of } \\
\text { Domestic } \\
\text { Debt) (i) }\end{array}$ & $\begin{array}{c}\text { Loans (\% } \\
\text { of } \\
\text { Domestic } \\
\text { Debt) (i) }\end{array}$ & $\begin{array}{c}\text { Other } \\
\text { accounts } \\
\text { payable } \\
\text { (\% of } \\
\text { Domestic } \\
\text { Debt) (i) }\end{array}$ & $\begin{array}{c}\text { Other } \\
\text { liabilities } \\
\text { (\% of } \\
\text { Domestic } \\
\text { Debt) (i) }\end{array}$ & $\begin{array}{c}\text { Long-term } \\
\text { debt (\% of } \\
\text { Domestic } \\
\text { Debt) (i) }\end{array}$ & $\begin{array}{l}\text { Short- } \\
\text { term debt } \\
\text { (\% of } \\
\text { Domestic } \\
\text { Debt) (i) }\end{array}$ & 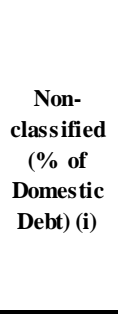 & $\begin{array}{c}\text { Long-term } \\
\text { debt (\% of } \\
\text { Domestic } \\
\text { Debt } \\
\text { excluding } \\
\text { Central } \\
\text { Bank } \\
\text { advances) } \\
\text { (i) }\end{array}$ & $\begin{array}{c}\text { Short- } \\
\text { term debt } \\
\text { (\% of } \\
\text { Domestic } \\
\text { Debt } \\
\text { excluding } \\
\text { Central } \\
\text { Bank } \\
\text { advances) } \\
\text { (i) } \\
\end{array}$ & 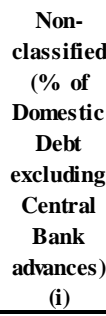 \\
\hline Burundi & HIPC & 46.7 & 19.7 & 27.0 & -91.1 & 9.3 & -100.3 & -0.3972 & 26 & 0 & 61 & 13 & 67 & 20 & 13 & 8 & 57 & 35 \\
\hline Comoros & HIPC & 51.2 & 6.2 & 44.9 & -46.2 & 1.7 & -47.9 & $-0.5552 *$ & & & & & & & & & & \\
\hline Eritrea & HIPC & 135.3 & 95.6 & 39.7 & 87.7 & 54.3 & 33.4 & $0.7503^{*}$ & & & & & & & & & & \\
\hline Ethiopia & HIPC & 32.2 & 14.2 & 18.1 & -103.3 & -10.0 & -93.3 & 0.1783 & 51 & 0 & 49 & 0 & 82 & 18 & 0 & 62 & 38 & 0 \\
\hline Ghana & HIPC & 45.5 & 24.2 & 21.4 & -36.7 & 8.9 & -45.6 & 0.0523 & 99 & 0 & 1 & 0 & 59 & 41 & 0 & 59 & 41 & 0 \\
\hline Guinea & HIPC & 66.8 & 10.8 & 56.0 & -15.0 & 7.9 & -22.9 & $-0.4974 *$ & 23 & 0 & 77 & 0 & 77 & 23 & 0 & 0 & 100 & 0 \\
\hline Guinea Bissau & HIPC & 44.1 & 18.3 & 25.7 & -276.2 & 12.2 & -288.3 & $-0.7893 *$ & 0 & 96 & 4 & 0 & 100 & 0 & 0 & 100 & 0 & 0 \\
\hline Haiti & HIPC & 24.5 & 14.3 & 10.2 & -14.0 & 1.3 & -15.3 & 0.0761 & 0 & 0 & 100 & 0 & 100 & 0 & 0 & 0 & 0 & 0 \\
\hline Kenya & & 50.2 & 25.9 & 24. & -6.9 & 12.1 & -19.1 & $-0.5018^{*}$ & 100 & 0 & 0 & 0 & 54 & 46 & 0 & 54 & 46 & 0 \\
\hline Kyrgyz & & 53.6 & 4.1 & 49.5 & 16.6 & -0.9 & 17.5 & 0.2531 & 100 & 0 & 0 & 0 & 73 & 27 & 0 & 73 & 27 & 0 \\
\hline Cambodia & & 31.2 & 0.5 & 30.6 & -35.2 & -1.8 & -33.4 & $0.9728^{*}$ & & & & & & & & & & \\
\hline Myanmar & & 25.0 & 24.9 & 0.0 & 0.8 & 1.9 & -1.1 & 0.2583 & & & & & & & & & & \\
\hline Malawi & HIPC & 43.3 & 22.9 & 20.4 & -61.7 & 13.2 & -74.8 & -0.3846 & 89 & 3 & 8 & 0 & 21 & 76 & 3 & 14 & 83 & 3 \\
\hline Nepal & & 35.5 & 14.6 & 20.9 & -31.8 & -0.2 & -31.5 & 0.4884 & 95 & 5 & 0 & 0 & 41 & 59 & 0 & 41 & 59 & 0 \\
\hline Rwanda & HIPC & 24.9 & 7.6 & 17.3 & -64.6 & -8.8 & -55.8 & $0.6800^{*}$ & 58 & 0 & 2 & 40 & 69 & 22 & 9 & 69 & 22 & 9 \\
\hline Solomon Islands & & 23.7 & 5.5 & 18.2 & -11.4 & -11.8 & 0.4 & $0.5497 *$ & 52 & 19 & 0 & 29 & 78 & 19 & 3 & 78 & 19 & 3 \\
\hline Sierra Leone & HIPC & 61.4 & 15.0 & 46.5 & -60.5 & 10.2 & -70.7 & 0.0945 & 90 & 0 & 9 & 1 & 36 & 64 & 0 & 30 & 70 & 0 \\
\hline Togo & HIPC & 27.5 & 10.0 & 17.5 & -72.7 & 3.3 & -76.0 & $-0.8138^{*}$ & & & & & & & & & & \\
\hline Tanzania & HIPC & 39.5 & 9.9 & 29.6 & -71.7 & -8.7 & -63.1 & $0.6393^{*}$ & 99 & 1 & 0 & 0 & 77 & 23 & 0 & 77 & 23 & 0 \\
\hline Uganda & HIPC & 28.9 & 9.8 & 19.1 & -32.7 & 8.2 & -41.0 & $0.7211^{*}$ & & & & & & & & & & \\
\hline Yemen & & 43.7 & 25.0 & 18.6 & -30.2 & 23.5 & -53.7 & $-0.5160^{*}$ & 88 & 0 & 12 & 0 & 18 & 82 & 0 & 10 & 90 & 0 \\
\hline
\end{tabular}

(i) Average share in 1996-2011. 


\section{References}

Abbas, A.S.M. (2005). "Public Debt Sustainability and Growth in sub-Saharan Africa: The Role of Domestic Debt". GDN Project on the Macroeconomics of Low Income Countries. Mimeo.

Abbas, A.S.M., Belhocine, N., El Ganainy, A., and M.A. Horton (2010). "A Historical Public Debt Database". IMF Working Paper No. 10/245.

Abbas, A.S.M., and J. Christensen (2010). "The Role of Domestic Debt Markets in Economic Growth: An Empirical Investigation for Low-Income Countries and Emerging Markets". IMF Staff Papers 57: 209-255.

Aiyar, S., Berg, A., and M. Hussain (2005). "The macroeconomic challenge of new aid". Finance and Development 42 (3). Washington, DC: International Monetary Fund.

Arnone, M., and A. Presbitero (2010). "Debt Relief Initiative: policy design and outcomes". Ashgate Publishing Co.

Bacchiocchi, E. and A. Missale (2012). "Multilateral Indexed Loans and Debt Sustainability". UNCTAD Discussion Papers No. 209.

BIS, European Central Bank, IMF (2009). "Handbooks on Securities Statistics". BIS, European Central Bank.

Borensztein, E., Levy-Yeyati, E., and U. Panizza (2006). "Living with Debt - How to Limit The Risks of Sovereign Finance". Cambridge, MA: Harvard University Press.

Calvo, G. (2005). "Emerging Capital Markets in Turmoil". MIT Press.

Cespedes L.F., Chang R. and A.Velasco (2000). "Balance Sheet and Exchange Rate Policy". National Bureau of Economic Research.

Christensen, J. (2005). "Domestic Debt Markets in Sub-Saharan Africa”. IMF Staff Papers 52(3): 518-538.

Diuof, M.A. and F. Dufrense (2012). "Financing Growth in the WAEMU through the Regional Securities Market: Past Successes and Current Challenges”. Washington, DC: International Monetary Fund. Working paper.

Easterly, W., and K. Schmidt-Hebbel (1991). "The macroeconomics of Public Sector Deficits. A synthesis". The World Bank.

Eichengreen B. , and R. Hausmann (1999). "Exchange rate and Financial Fragility". National Bureau of Economic Research.

Eichengreen B., R. Hausmann , and U. Panizza (2003). "The pain of original sin", in Other People's Money: Debt Denomination and Financial Instability in Emerging Market Economics (University of Chicago Press, 2004).

Fischer, S., and W. Easterly (1990). "The Economics of the Government Budget Constraint," The World Bank Research Observer, Vol. 5, No. 2, pp. 127-42.

Guscina, A. (2008). "Impact of Macroeconomic, Political, and Institutional Factors on the Structure of Government Debt in Emerging Market Countries". IMF Working Paper 08/205.

Hanson, J.A. (2007). "The Growth in Government Domestic Debt: Changing Burdens and Risks". World Bank Policy Research Working Paper No. 4348.

Hauner, D. (2006). "Fiscal policy and financial development". IMF Working paper 06/26.

Hausmann, R.. (2003). "Good Credit Ratios, Bad Credit Ratings: The Role of Debt Denomination," in Rules-Based Fiscal Policy in Emerging Markets: Background, Analysis and Prospects, G. Kopits (editor), London: Macmillan. 
Hausmann, R. and R. Rigobon (2003). "On the Benefits of Changing the Currency Denomination of Concessional Lending to Low-Income Countries". Cambridge, Mass., Harvard University. Unpublished.

Hausmann, R., and U. Panizza (2003). "On the determinants of Original Sin: an empirical investigation". Journal of International Money and Finance.

Hausmann, R., Panizza, U., and R. Rigobon (2006). "The long-run volatility puzzle of the real exchange rate". Journal of International Money and Finance 25 (1): 93-124.

International Development Association (2006). "IDA countries and Non-Concessional Debt: dealing with the "free rider" problem in IDA14 grant-recipient and post-MDRI countries". Resource Mobilization Department.

International Monetary Fund (2000). "Monetary and Financial Statistical Manual". Washington, DC: International Monetary Fund.

International Monetary Fund (2001). “Global Financial Statistics Manual”. Washington, DC: International Monetary Fund.

International Monetary Fund (2003). "External Debt Statistics: Guides for Compilers and Users". Washington, DC: International Monetary Fund.

International Monetary Fund (2009). "Staff Guidance Note on Debt Limits in Fund-Supported Programs". Washington, DC: International Monetary Fund.

International Monetary Fund (2010). "Emerging from the Global Crisis: Macroeconomic Challenges facing Low-Income Countries". Washington, DC: International Monetary Fund.

International Monetary Fund (2011b). "Public Sector Debt Statistics. Guide for Compilers and Users". Washington, DC: International Monetary Fund.

International Monetary Fund and International Development Association (2012). "Revisiting Debt Sustainability Framework for Low Income Countries". Washington, DC: International Monetary Fund.

International Monetary Fund and The World Bank (2001). "Developing Government Bond Markets: A Handbook". Washington, DC: International Monetary Fund and The World Bank.

Jeanne O. (2003). "Why do Emerging Market Economies Borrow in Foreign Currency?". IMF WP No. 03/177.

Johnson, A. (2001). “Key issues for analyzing domestic debt sustainability”. Debt Relief International Ltd.

Kumhof, M., and E. Tanner (2005). "Government Debt: A Key Role in Financial Intermediation”. IMF Working Paper No. 05/57.

Mehl, A., and J. Reynaud (2005). "The determinants of "domestic" original sin in Emerging Market Economies". European Central Bank. Working paper series. No. 560/December 2005.

Mehrotra, A.N., K. Miyajima, and A. Villar (2012). Developments of domestic government bond markets in EMEs and their implications, in Fiscal policy, public debt and monetary policy in emerging market economies, Bank for International Settlements, 67: 31-50.

Presbitero, A. (2012a). "Total Public Debt and Growth in Developing Countries". European Journal of Development Research 24(4): 606-626.

Presbitero, A. (2012b). "Domestic Debt in Low Income Countries". Economics Bulletin 32(2): 1099-1112.

Reinhart, C., and K. Rogoff (2009). "This Time Is Different: Eight Centuries of Financial Folly". Princeton, New Jersey: Princeton University Press.

Rodrik, D. (2008). "The Real Exchange Rate of Economic Growth". John F. Kennedy School of Government. 
Sturzenegger F. and J. Zettelmeyer (2006). "Debt Defaults and Lessons from a Decade of Crisis". The MIT Press.

United Nations Conference on Trade and Development (2004). "Debt Sustainability: Oasis or Mirage?". New York and Geneva: United Nations. 